\title{
THE ACTAVIS INFERENCE: THEORY AND PRACTICE
}

\author{
Aaron Edlin, Scott Hemphill, Herbert Hovenkamp \& Carl Shapiro ${ }^{\dagger}$
}

\begin{abstract}
In FTC v. Actavis, Inc., the Supreme Court considered "reverse payment" settlements of patent infringement litigation. In such a settlement, a patentee pays the alleged infringer to settle, and the alleged infringer agrees not to enter the market for a period of time. The Court held that a reverse payment settlement violates antitrust law if the patentee is paying to avoid competition. The core insight of Actavis is the Actavis Inference: a large and otherwise unexplained payment, combined with delayed entry, supports a reasonable inference of harm to consumers from lessened competition.

This paper is an effort to assist courts and counsel in implementing the Actavis Inference. First, we evaluate a variety of fact patterns that have arisen in the district courts since Actavis, including payment that takes a form other than cash. For example, a branded drug maker may promise not to offer an authorized generic drug. As we explain, under Actavis, such agreements are especially likely to violate antitrust law. We also consider how much detail a plaintiff must offer in its initial complaint to comply with federal pleading requirements.
\end{abstract}

$\dagger$ Aaron Edlin is the Richard Jennings Professor of Law and Professor of Economics at the University of California at Berkeley, and Research Associate, National Bureau of Economic Research; Scott Hemphill is the Caryl Louise Boies Visiting Professor of Law at New York University and Professor of Law (on leave) at Columbia University; Herbert Hovenkamp is the Ben V. \& Dorothy Willie Professor of Law, University of Iowa; Carl Shapiro is the Transamerica Professor of Business Strategy at the Haas School of Business at the University of California at Berkeley. Hemphill and Shapiro have been retained as consultants and possible expert witnesses in antitrust cases involving reverse payments; Hovenkamp has been consulted as a non-testifying expert. We thank Joseph Farrell and Steve Salop for helpful discussions that improved the paper. 
Second, we demonstrate that the Actavis Inference fully applies when multiple generic firms, rather than just one, threaten to enter the market. Our economic model shows that the Actavis Inference becomes stronger and more important in the presence of multiple generic firms. Our analysis demonstrates that the contrary conclusions reached in a recent paper by Bruce Kobayashi, Joshua Wright, Douglas Ginsburg, and Joanna Tsai ("KWGT") are incorrect, inconsistent with KWGT's own analysis, or irrelevant to a faithful implementation of Actavis.

Third, we clarify the reasons not to litigate patents in antitrust cases. Thanks to the Actavis Inference, a trial court need not determine patent validity or infringement in order to assess the legality of the settlement. The antitrust question depends upon the ex ante prospects in patent litigation and not ex post litigation of the patent by a patent court or by the antitrust court considering the settlement. Litigating the patent is thus of limited probative value and not dispositive regarding a potential antitrust violation.

\section{INTRODUCTION}

In FTC $v$. Actavis, Inc., ${ }^{1}$ the Supreme Court considered the proper antitrust treatment of a payment made by a patent owner to an alleged infringer in settlement of their infringement litigation, wherein the alleged infringer agrees not to enter the market until some date prior to the expiration of the patent. The Court held that such "reverse payment" settlements are illegal if the patent holder is paying to avoid competition. ${ }^{2}$ Such settlements are fairly called "pay-for-delay" settlements. The Court held, however, that not all reverse payment settlements are presumed to be illegal, rejecting the FTC position, because they do not all necessarily involve payment for delay. ${ }^{3}$ The question is when a court can reasonably infer that a reverse payment is a payment for delay, or in other words, a payment to avoid competition.

While most settlements of patent infringement disputes raise no antitrust issues, pay-for-delay settlements differ in important ways. In most traditional settlements, the defendant pays the patentee a royalty and produces under the patent. Production licenses are expressly authorized by the Patent Act. Even production licenses that contain limitations on the licensee's output are lawful most of the time, even if

1. 133 S. Ct. 2223 (2013).

2. Id. at 2236 ("[T] he payment (if otherwise unexplained) likely seeks to prevent the risk of competition. And, as we have said, that consequence constitutes the relevant anticompetitive harm.").

3. Id. at 2237-38. 
made outside the litigation context. They are a form of technology sharing that presumptively increases overall output. By contrast, a payfor-delay settlement does not involve a license at all, but at most a promise to license at some future time. Pending that, it is simply a naked market division agreement.

Secondly, in conventional patent litigation the plaintiff and defendant are adverse on issues of validity, infringement, and remedy. The plaintiff has a strong interest in having validity and infringement established, while the defendant has a strong but opposite interest. By contrast, the Hatch-Waxman Act's provision forbidding entry by third firms until 180 days after the defendant (generic) produces-even when the defendant chooses not to produce as part of the settlement-gives the parties a strong joint incentive to use a settlement to delay the entry of follow-on generic producers. ${ }^{4}$ The joint maximizing position for them is to preserve patent exclusivity for as long as possible, but share the proceeds. The only issue on which they have adversity is the size of the payment, which is simply a wealth transfer between the two of them. The more likely the patent is to be invalid or not infringed, all else equal, the larger that payment will be.

According to Actavis, the trial court need not determine validity or infringement of the patent in order to assess the legality of a reverse payment settlement under the antitrust laws. ${ }^{5}$ Unlawfulness requires a reasonable inference of harm to consumers from lessened competition, which can be established by identifying a large and otherwise unexplained payment of cash or something else of value made by the patent holder to the alleged infringer in exchange for that firm's agreement not to enter the market for some period of time. We call this the Actavis Inference.

So far, these cases have arisen in the pharmaceutical industry, where the patent holder ("Brand") is selling a branded pharmaceutical product and the alleged infringer ("Generic") is planning to offer a bioequivalent generic drug. In this context, the Actavis Inference enables the courts to infer that a large, otherwise unexplained transfer of value from Brand to

4. In an ordinary patent case, if an alleged infringer agrees to leave a market or delay entry as part of a patent settlement, other firms that think the patent weak may still enter, potentially eliminating the gains from delay. In contrast, under the Hatch-Waxman Act, the FDA will not approve a third party's application to enter before 180 days subsequent to the first generic beginning production. Id. at 2228-29. Third parties therefore would find early entry much more difficult in the Hatch-Waxman context which greatly increases the joint incentives of the brand and the first generic to agree to delay entry. Id.

5. Id. at 2236 ("It is normally not necessary to litigate patent validity to answer the antitrust question ...."). In Part V, we explain that litigating the patent would, not in any event, be dispositive regarding a potential antitrust violation and of limited probative value. 
Generic was made to delay generic entry. ${ }^{6}$ Part II below briefly sketches out the logic behind the Actavis Inference and provides some background for our subsequent analysis.

Shortly after the Supreme Court issued its opinion in Actavis, we wrote a paper, Activating Actavis, designed to help the courts and counsel implement the Actavis decision. ${ }^{7}$ We subsequently wrote a second paper, Actavis and Error Costs, in response to critics of Activating Actavis. ${ }^{8}$ Now we write again for three reasons.

First, the passage of time allows us to evaluate how district courts have implemented the Actavis Inference and to make recommendations. We continue to believe that the Actavis Inference is both important to prevent anticompetitive settlements and workable in practice. We expect it will take some time for the case law to become settled in this area, since a wide variety of fact patterns arise and the Supreme Court left a number of issues unresolved. Reverse payment settlements in which Brand agrees not to offer a so-called "authorized generic" version of the drug in question are of particular concern. As explained in Part III below, under Actavis these agreements are especially likely to violate the antitrust laws.

Second, we write to provide additional economic analysis that is directly relevant to the Actavis Inference. More specifically, in Part IV we present an economic model in which multiple generic firms, rather than just one, are threatening to enter the market. ${ }^{9}$ Many cases involve multiple generic (potential) entrants, and the real bite of the HatchWaxman Act is its limitation on multiple entry, so we consider this economic analysis important in practice. Our economic model shows that the Actavis Inference becomes stronger and more important in the presence of multiple generic firms rather than just one generic firm. More precisely, we show that the incentive of the patent holder to pay the first

6. Under the burden shifting analysis applied in King Drug Co. of Florence v. Cephalon, Inc., the plaintiff would have the burden to show that the payment was "large," but the burden would then shift to the defendant to show that it was not "unexplained." No. 06-CV-1797, 2015 U.S. Dist. LEXIS 9545, at *24 (E.D. Pa. Jan. 28, 2015). The court cited the fact that evidence about the explanation is more likely to be in the hands of the defendant. Id. Once the defendant has met this burden, the plaintiff could still show that the defendant's proffered justifications were pretextual or defeated by the existence of a less restrictive alternative. Id. at ${ }^{25}$.

7. Aaron Edlin, Scott Hemphill, Herbert Hovenkamp \& Carl Shapiro, Activating Actavis, ANTITRUST, Fall 2013, at 16 [hereinafter Activating Actavis].

8. Aaron Edlin, Scott Hemphill, Herbert Hovenkamp \& Carl Shapiro, Actavis and Error Costs: A Reply to Critics, ANTITRUST SouRCE, Oct. 2014, at 1 [hereinafter Actavis and Error Costs].

9. The economic model in Activating Actavis included the patent holder and a single alleged infringer. 
generic entrant to delay entry is greater if more generic entrants are waiting in the wings. With multiple generic entrants, a large reverse payment is even more likely to be made in exchange for limiting competition, because competition is even more to be feared. This analysis demonstrates that the contrary conclusions reached in a recent paper by Bruce Kobayashi, Joshua Wright, Douglas Ginsburg, and Joanna Tsai ("KWGT") ${ }^{10}$ are incorrect, inconsistent with KWGT"s own analysis, or irrelevant to a faithful implementation of Actavis.

Third, we clarify the reasons not to litigate patent validity in the antitrust case. The Court in Actavis wrote, "[i]t is normally not necessary to litigate patent validity to answer the antitrust question." 11 In Part V, we explain that the antitrust question depends upon the ex ante prospects in patent litigation and not ex post litigation of the patent by a patent court or by the antitrust court considering the settlement. Litigating the patent would be of limited probative value and not dispositive regarding a potential antitrust violation. This observation is particularly important for those cases where the patent has been adjudicated. A finding of invalidity or noninfringement, for example, does not mean that a patent settlement is anticompetitive; conversely, a finding of validity and infringement does not absolve the patent settlement of anticompetitive effects.

\section{THE ACTAVIS INFERENCE}

Justice Breyer's opinion in Actavis established the Actavis Inference. Put simply, in the pharmaceutical context: if Brand pays more than its prospective litigation costs to Generic, a firm threatening entry with a generic version of the same drug; and if Generic agrees not to offer that version for some period of time; then a fact-finder may properly infer that such a "large and unexplained"12 payment was made to delay generic entry, and hence is anticompetitive.

One significant holding of Actavis is that a reverse payment settlement can be unlawful even though it falls within the "scope of the

10. Bruce Kobayashi, Joshua Wright, Douglas Ginsburg \& Joanna Tsai, Actavis and Multiple ANDA Entrants: Beyond the Temporary Duopoly, ANTTTRUST, Spring 2015, at 89 [hereinafter KWGT]. This article is an abridgement of a longer paper bearing the same title available at http://ssrn.com/abstract $=2508094$ (Dec. 7, 2014) [hereinafter KWGT Working Paper]. Beyond the specific reasons given in Part IV, the KWGT analysis is unhelpful as a guide to courts or counsel because it offers a rejection and critique of the Court's decision in Actavis, rather than a faithful implementation of the Court's instructions.

11. FTC v. Actavis, Inc., 133 S. Ct. 2223, 2236 (2013).

12. Id. 
patent." In the particular case of reverse payment settlements involving branded and generic drugs, the "scope" question usually refers to a patent's duration..$^{13}$ A settlement is said to be within the patent's scope if it permits generic entry at some point prior to the patent's expiration date. The Court held that such agreements are to be assessed under antitrust's rule of reason. Within the rule of reason, anticompetitive effect and market power can be inferred from the large payment itself, if the payment was larger than the patent holder's anticipated litigation costs. ${ }^{14}$ That is the essence of the Actavis Inference. ${ }^{15}$

In Activating Actavis, we explained at length that the Actavis Inference is strongly supported by economic analysis and consistent with prior Supreme Court jurisprudence. ${ }^{16}$ In Actavis and Error Costs, we further explained why the Actavis Inference is critical to avoid a substantial risk of false negative results, i.e., situations in which antitrust plaintiffs would otherwise be unable to challenge anticompetitive settlements effectively. ${ }^{17}$

The Actavis Inference is important because Brand and Generic have very strong incentives to agree to delay entry into the market by the generic firm. Delayed entry by Generic preserves Brand's monopoly. Since monopoly profits are greater than the total profits if two or more firms are competing, the two firms will maximize their combined profits by delaying generic entry until the patent expires, provided antitrust

13. In general, conduct "outside the scope" of the patent can mean many things, from the tying of unpatented goods to overly broad claim constructions or agreements requiring the payment of royalties after a patent's expiration. See Herbert Hovenkamp, The Rule of Reason and the Scope of the Patent, 52 SAN DIEGO L. REV. (forthcoming 2015); Michael A. Carrier, Why the "Scope of the Patent" Test Cannot Solve the Drug Patent Settlement Problem, 16 Stan. Tech. L. REv. 1, 5-6 (2012) (assessing the evolution of the test in the context of reverse payment settlements, prior to its rejection by the Supreme Court).

14. Actavis, $133 \mathrm{~S}$. Ct. at 2236-37; see also King Drug Co. of Florence v. Cephalon, Inc., No. 06-CV-1797, 2015 U.S. Dist. LEXIS 9545, at *23 (E.D. Pa. Jan. 28, 2015), which followed this inference, rejecting the defendant's argument that the size of the payment must be assessed "in comparison to the brand manufacturer's expected monopoly profits in the absence of generic competition." Id. at *56. Rather, the court followed the plaintiffs' suggestion "that a reverse payment is sufficiently large if it exceeds saved litigation costs and a reasonable jury could find that the payment was significant enough to induce a generic challenger to abandon its patent claim." Id. at *56-58. It then denied summary judgment on evidence that the avoided litigation costs did not exceed $\$ 13$ million but the payment was much larger.

15. Defendants in one post-Actavis case have nevertheless argued that "delay" requires a delay past the patent's expiration. The district court correctly rejected that argument. See United Food \& Commercial Workers Local 1776 v. Teikoku Pharma USA, Inc., No. 14-MD-02521, 2014 WL 6465235, at *8-11 (N.D. Cal. Nov. 17, 2014) (denying motion to dismiss premised on mere fact of entry prior to patent expiration).

16. Activating Actavis, supra note 7.

17. Actavis and Error Costs, supra note 8. 
allows them to do so. Since generic entry greatly erodes the branded firm's profits, the incentives to enter into such an anticompetitive agreement can be very strong. Such an agreement would deny consumers any possibility of competition during the lifetime of the patent. The Court emphasized that no matter how small the risk of invalidity or noninfringement, a patent holder who pays to avoid that risk violates antitrust law:

The owner of a particularly valuable patent might contend, of course, that even a small risk of invalidity justifies a large payment. But, be that as it may, the payment (if otherwise unexplained) likely seeks to prevent the risk of competition. And, as we have said, that consequence constitutes the relevant anticompetitive harm. ${ }^{18}$

The Court identified a large and unexplained payment as a suspicious act that suggests the patent holder is paying to limit competition.

By contrast, the Actavis dissenters would have approved any settlement within the scope of the patent. ${ }^{19}$ As they observed, such an agreement would be no worse from consumers' perspective than a determination that the patent was valid and could be enforced for the remainder of its term. ${ }^{20}$ Treating all settlements "within the scope of the patent" 21 as legal under the antitrust laws heavily favors antitrust defendants, since the patent might have been found invalid or not infringed if the patent case had been litigated. The dissent's position effectively presumes that Brand would have won its case with certainty. But as we have argued, that conclusive presumption is inconsistent with observing a large payment. If Brand knew for certain that it would win

18. Actavis, $133 \mathrm{~S}$. Ct. at 2236. See also In re Aggrenox Antitrust Litig., No. 14-MD2516, 2015 U.S. Dist. LEXIS 35634, at *44 (D. Conn. Mar. 23, 2015) ("Large reverse payments that are not particularly large in relation to the value of the patent may show confidence in the patent, but if they represent payment to avoid the risk of invalidation, then they still run afoul of Actavis.").

19. Id. at 2238 (Roberts, C.J., dissenting) (arguing that "a patent . . provides an exception to antitrust law, and the scope of the patent-i.e., the rights conferred by the patent-forms the zone within which the patent holder may operate without facing antitrust liability").

20. This point assumes that the patent holder who wins the patent infringement case would receive an injunction preventing the infringing firm from practicing the patent for the remainder of its term.

21. Actavis, 133 S. Ct. at 2238 (Roberts, C.J., dissenting). 
the patent suit, there would be no reason for Brand to pay the alleged infringer more than the Brand's prospective litigation costs.

The Actavis Inference provides a relatively clear and direct route by which an antitrust plaintiff can establish an inference that a reverse payment settlement harms competition and thus violates the antitrust laws. However, nothing in Actavis indicates that this is the only route an antitrust plaintiff can take. Indeed, Actavis establishes that an antitrust plaintiff challenging a patent settlement can prevail by showing that the patent holder paid the alleged infringer to delay its entry into the market and thereby restrict competition. In some cases this may be possible without invoking the Actavis Inference, e.g., if there is other contemporaneous evidence indicating that the purpose and effect of a reverse payment was to delay entry. Actavis does not establish a safe harbor for patent settlements involving reverse payments that are less than litigation costs.

\section{REVERSE PAYMENT SETtLEMENTS IN THE DistRICT COURTS Since ACTAVIS}

District courts have begun to address several distinct fact patterns that have arisen in cases where reverse payments have been challenged on antitrust grounds. In this Part, we address several of these fact patterns. We continue to believe that the economic logic underlying the Supreme Court's Actavis decision, which forms the basis for the Actavis Inference, is robust and flexible and can be applied in practice without undue difficulty in a wide range of cases.

\section{A. Cash us. Noncash Payments}

While the Court referred repeatedly in the Actavis decision to a "cash" payment from the patent holder to the alleged infringer, the economic logic articulated by the Court applies regardless of the payment's form. Restricting the Actavis Inference to payments made in "cash" would open up a gaping loophole: the patent holder could purchase corporate shares in General Motors, transfer the shares to the generic, and evade Actavis because no cash changed hands. Furthermore, if forms of payment that are less liquid or more difficult to value are exempt from the Actavis Inference, settling firms will have an incentive to use those forms of payment rather than cash, creating additional inefficiencies, compounding the basic problem. 
We were therefore quite surprised when two district courts ruled recently that the Actavis Inference only applies to "cash" payments. ${ }^{22}$ In the Lamictal case, the court stated that "the Supreme Court considered a reverse payment to involve an exchange of money." 23 The court then rejected the Black's Law Dictionary definition of "payment" as "the delivery of money or some other valuable thing accepted in partial or full discharge of an obligation." ${ }^{4}$ The court even acknowledged that Chief Justice Roberts' dissent in Actavis repeatedly observed that the majority's logic must sweep in "other consideration" and "alternative arrangements." 25 We expect that the appellate courts will reject such a cramped interpretation of payment. ${ }^{26}$

At this writing, seven other district courts have explicitly addressed this same issue, considering settlements on six drugs; these courts have been more faithful to the logic in Actavis, finding that the form of the reverse payment does not matter for the purposes of the Actavis Inference. ${ }^{27}$ We urge other courts to follow this route.

As a practical matter, when the transfer of value from the patent holder to the alleged infringer takes a form other than cash, some

22. In re Loestrin 24 Fe Antitrust Litig., No. 1:13-MD-2472, 2014 WL 4368924, at * 12 (D.R.I. Sept. 4, 2014) (concluding that payment must be in cash based on the "literal holding of Actavis," while noting the resulting "quandary" that under this interpretation, settling parties "are likely to evade Sherman Act scrutiny"); In re Lamictal Direct Purchaser Antitrust Litig., 18 F. Supp. 3d 560, 565 (D.N.J. 2014) (reading Actavis to require that the settlement "must include money").

23. Lamictal, 18 F. Supp. 3d at 568.

24. Id. (quoting BLACK'S LAW DICTIONARY 1243 (9th ed. 2010)).

25. Id. (quoting Actavis, $133 \mathrm{~S}$. Ct. at 2245 (Roberts, C.J., dissenting)). The court then found the contrary reasoning in other courts' conclusions, as discussed below, to be "unpersuasive." Id. at 569.

26. At this writing, Lamictal has been argued and is pending before the Third Circuit, and Loestrin is awaiting briefing in the First Circuit.

27. These district courts have analyzed settlements involving Aggrenox, Effexor XR, Lipitor, Niaspan, Nexium (two courts), and Lidoderm. In re Aggrenox Antitrust Litig., No. 14-MD-2516, 2015 U.S. Dist. LEXIS 35634, at *40-41 (D. Conn. Mar. 23, 2015); In re Effexor XR Antitrust Litig., No. 11-CV-5479, 2014 WL 4988410, at *20 (D.N.J. Oct. 6, 2014) (concluding that payments are not limited to cash, but that plaintiffs must provide a reliable basis for assertions of non-cash payment); In re Lipitor Antitrust Litig., No. 12-CV. 2389, 2013 WL 4780496, at *26 (D.N.J. Sept. 5, 2013) ("[N]othing in Actavis strictly requires that the payment be in the form of money ...."); In re Niaspan Antitrust Litig., No. 13-MD2460, 2014 WL 4403848, at *11 (E.D. Pa. Sept. 5, 2014) ('[T] he term 'reverse payment' is not limited to a cash payment."); In re Nexium (Esomeprazole) Antitrust Litig., 968 F. Supp. $2 \mathrm{~d}$ 367, 392 (D. Mass. 2013) ("Nowhere in Actavis did the Supreme Court explicitly require some sort of monetary transaction . . . "); Time Ins. Co. v. Astrazeneca AB, No. 14-4149, 2014 WL 4933025, at *3 (E.D. Pa. Oct. 1, 2014) (Nexium) ("[R]everse payments deemed anti-competitive pursuant to Actavis may take forms other than cash payments."); United Food \& Commercial Workers Local 1776 v. Teikoku Pharma USA, Inc., No. 14-MD-02521, 2014 WL 6465235, at *11-12 (N.D. Cal. Nov. 17, 2014) (Lidoderm). 
additional analysis will be required to quantify the dollar value of the reverse payment. This analysis is likely to depend heavily on the specific facts of the case at hand and may well require a benchmarking exercise that compares the case at hand to experience in similar markets. Importantly, this analysis should be conducted from the perspective of the patent holder. This follows from the economic logic underlying the Actavis Inference: if the settlement involves the patent holder's sacrifice of something with greater value to it than its own prospective litigation costs, it is reasonable to presume that the patent holder is paying for some protection from competition..$^{28}$

Therefore, for noncash reverse payments, the courts should seek to measure the dollar value sacrificed by the patent holder as a result of the agreement it reached with the alleged infringer. ${ }^{29} \mathrm{~A}$ pharmaceutical example illustrates in general terms how this exercise is likely to play out in court. Suppose the settlement involves Brand granting a license to Generic to produce and market a second drug. Suppose further that Brand will earn $\$ 100$ million in royalties and Generic will make $\$ 25$ million in economic profits under that license. Importantly, suppose there is evidence from other licenses in the industry or from internal company documents that if instead of licensing to Generic, Brand had made an arms-length, stand-alone license for the second drug, Brand would expect to earn $\$ 150$ million in royalties while giving the licensee zero economic profits. ${ }^{30}$ With this fact pattern, the settlement involves a $\$ 50$ million profit sacrifice by Brand, ${ }^{31}$ which is greater than the $\$ 25$ million value of the license to Generic. ${ }^{32}$

28. As we have noted in previous work, although a sacrifice by the patent holder is the primary focus of the present analysis, a sacrifice is not the only route to establishing an anticompetitive effect. See Activating Actavis, supra note 7, at n.22.

29. The same principle applies for reverse payments made in cash. For cash payments, the profit sacrificed by the patent holder is simply the amount of the reverse payment.

30. Economic profits are defined as profits in excess of a normal, risk-adjusted return on capital. If several equally capable licensees compete vigorously to sign the license with Brand for the second drug, their economic profits will be driven toward zero.

31. The $\$ 50$ million profit sacrifice results from Brand earning $\$ 100$ million rather than $\$ 150$ million in royalties.

32. In this example, the value of the license to Generic, $\$ 25$ million, is less than the profit sacrifice by Brand, which is $\$ 50$ million. The example is purposefully designed so that the combined profits of $\$ 125$ million under Brand's license with Generic are less than the combined profits of $\$ 150$ million earned under the arms-length, stand-alone license. This "value destruction" will occur if (for example) Generic is not the best-qualified licensee for the second drug. Here, using the less-capable Generic as the licensee for the second drug results in a $\$ 25$ million destruction in combined value, $\$ 125$ million rather than $\$ 150$ million. This is an example of the type of inefficiency that can result if companies use non- 


\section{B. Promises Not to Offer an Authorized Generic Drug}

A number of reverse payment settlements have involved promises on the part of the branded pharmaceutical firm not to offer an authorized generic ("AG") version of the same drug. We now describe AGs and explain how these agreements should be analyzed under the Actavis decision.

\section{Authorized Generic Drugs}

An AG is a generic version of a drug, authorized by a branded drug maker under its own FDA approval. The branded firm may market the drug itself or, more commonly, contract with a generic drug maker to do so. AGs have been an important feature of generic product launches since the 2000s. ${ }^{33}$ Courts have consistently held that an AG may be marketed even during the 180-day exclusivity period of an independent generic drug maker provided for in certain circumstances under the HatchWaxman Act. ${ }^{34}$

There are several reasons why the supplier of the branded drug may choose to introduce or enable an AG version. The AG will typically be priced lower than the branded drug, which can enable the supplier of the branded drug to engage in price discrimination. Such price discrimination increases profits and might also increase output and benefit consumers. This strategy is hardly unique to pharmaceuticals. Firms commonly offer multiple products targeted at different market segments, and they often use different brand names for high-end products than for low-end products.

One should bear in mind that the branded product and the AG are not independent rivals, even if they superficially appear to compete. In cases where the firm selling the branded product introduces its own AG, this is clear enough. But even in cases where the branded firm contracts with a generic drug maker to market the AG product, that firm is not truly an independent rival. Rather, it is dependent on the branded firm,

cash forms of payment in reverse-payment patent settlements in an attempt to avoid antitrust liability.

33. FTC, Authorized GENeric DRUGS: Short-Term EFFECTS AND LONG-TERM IMPACT 26-27 \& fig.2-7 (2011) (analyzing generic launches with 180-day exclusivity for branded drug administered as capsule or tablet, and finding that for fifty-five launches between 2003 and 2008,33 , or 61 percent, included an AG).

34. Mylan Pharm., Inc. v. FDA, 454 F.3d 270, 271 (4th Cir. 2006); Teva Pharm. Indus. v. FDA, 410 F.3d 51, 52 (D.C. Cir. 2005); see also Sanofi-Aventis v. Apotex, Inc., 659 F.3d 1171, 1174-75 (Fed. Cir. 2011) (taking this point for granted). 
which sets the quantity and pricing terms of the marketing arrangement and may share in the profits.

Despite these qualifications, the presence of an authorized generic version injects some additional competition into the market, above and beyond that offered by the branded product and any generic products supplied by other firms. From an antitrust perspective, this additional competition can be especially significant if there would otherwise be only one independent generic supplier.

\section{No-Authorized-Generic Provisions}

A promise by the branded pharmaceutical firm not to introduce or permit an AG is generally referred to as a "no-AG" provision. A no-AG provision is clearly costly to the branded pharmaceutical firm, since it constrains that firm's future business choices. No-AG provisions also are clearly valuable to the independent generic firm. A no-AG provision is especially valuable to a generic firm poised to enjoy the 180-day exclusivity period.

As discussed in the previous subpart, two district courts have held that Actavis is limited to cash. In both, the alleged noncash compensation included a no-AG deal, which these courts therefore rejected as a basis for the Actavis Inference. ${ }^{35}$ Five others have recognized that no-AG deals are a form of payment. ${ }^{36}$ Yet another district court, while acknowledging the above referenced evidence about output and price effects of authorized generic entry in theory, nevertheless concluded that the value of a branded firm's promise not to enter the market was so "vague and amorphous" that as pleaded, it could not be counted as a payment for delay. ${ }^{37}$

This reaction is in sharp contrast to the concretely high value placed on no-AG provisions by both branded and generic firms. Real-world evidence of that value recently emerged in the first reverse payment trial

35. In re Loestrin 24 Fe Antitrust Litig., No. 13-MD-2472, 2014 WL 4368924, at *12 (D.R.I. Sept. 4, 2014); In re Lamictal Direct Purchaser Antitrust Litig., No. 12-CV-995, 2014 WL 282755 , at *5 (D.N.J. Jan. 24, 2014).

36. The drugs are Aggrenox, Lidoderm, Niaspan, and Nexium (two district courts). In re Aggrenox Antitrust Litig., No. 14-MD-2516, 2015 U.S. Dist. LEXIS 35634, at *48-51 (D. Conn. Mar. 23, 2015); United Food \& Commercial Workers Local 1776 v. Teikoku Pharm. USA, Inc., No. 14-MD-02521, 2014 WL 6465235, at *12 (N.D. Cal. Nov. 17, 2014) (Lidoderm); In re Niaspan Antitrust Litig., No. 13-MD-2460, 2014 WL 4403848, at *11 (E.D. Pa. Sept. 5, 2014); In re Nexium (Esomeprazole) Antitrust Litig., 968 F. Supp. 2d 367, 392 (D. Mass. 2013); Time Ins. Co. v. Astrazeneca AB, No. 14-4149, 2014 WL 4933025, at *3-4 (E.D. Pa. Oct. 1, 2014) (Nexium) (agreeing with In re Nexium).

37. In re Effexor XR Antitrust Litig., No. 11-CV-5479, $2014 \mathrm{WL} 4988410$, at *21 (D.N.J. Oct. 6, 2014). 
after Actavis. At trial, purchasers and end-payors for Nexium, a blockbuster heartburn drug, argued that AstraZeneca paid first-filer Ranbaxy to delay entry by agreeing to a no-AG provision. In particular, plaintiffs offered a short memorandum prepared by outside counsel describing Ranbaxy's anticipated bargaining position and AstraZeneca's strategy in response. ${ }^{38}$ The strategy centered on offering a no-AG provision. As counsel candidly explained, "Ranbaxy likely will want a settlement that preserves its 180-day period of exclusivity against other generics and also guarantees that exclusivity against authorized generic competition, and it may be willing to agree to a relatively late entry date in a settlement that provides it with sole exclusivity." 39

In any case where the plaintiff asserts that a no-AG provision constitutes all or part of a large and unexplained reverse payment, the plaintiff will need to present evidence allowing the court to reasonably approximate how much money the branded firm sacrificed by agreeing not to introduce or enable an AG version. Evidence regarding the profits the branded firm expected to earn from an AG will be especially relevant for this inquiry. Only rarely will it be possible to compute the value of a no-AG provision with great precision, as one would with a strictly cash payment. But it should often be possible to approximate that value under reasonable economic assumptions. As a result, we believe that a no-AG provision is a form of reverse payment whose value can be estimated and made fully subject to the Actavis Inference.

More problematically, a no-AG provision places a second naked market division agreement on top of the first agreement to delay generic entry in exchange for a large payment. Nevertheless, courts thus far have taken the view, albeit with little analysis, that no-AG agreements must be assessed together with the rest of the deal under the rule of reason, rather than viewing them as independently unlawful per se. ${ }^{40}$ It bears repeating that pay-for-delay settlements are not mere licenses over the term of the delay, but horizontal agreements not to compete, and no-AG provisions make a bad situation worse. In fact, the no-AG provision is more harmful to competition than a cash settlement of the same magnitude. The cash settlement operates as a mere wealth transfer from the brand to the generic, delaying entry but with little impact on generic

38. Timothy Hester, Nexium Settlement Considerations (Aug. 3, 2007). The memo was introduced at trial as Exhibit 140, and attached as Exhibit D to Motion for Permanent Injunction, In re Nexium (Esomeprazole) Antitrust Litigation, No. 12-MD-2409 (D. Mass. Jan. 7, 2015) (No. 1457).

39. Id.

40. This is the case, explicitly or implicitly, with the district court opinions considering no-AG deals discussed above. 
output once generic entry takes place. By contrast, the no-AG provision compensates the independent generic in a more sinister fashion, by giving it protection from competition that would otherwise occur and thus keeping up prices at consumers' expense. Worse yet, a legal rule that permitted no-AG provisions while condemning large cash payments would induce firms to choose the more harmful former alternative.

Nor can a no-AG provision be defended on the grounds that it is nothing more than an exclusive license, which patent holders generally have the statutory right to grant. ${ }^{41}$ That statutory argument might apply if Brand's no-AG commitment were combined with a patent license that allowed Generic to enter the market immediately, but at the time the no$\mathrm{AG}$ provision is negotiated there is no marketing under a license at all, but at most a promise to license at some time in the future. Clearly, the Actavis Court did not believe that a pay-for-delay settlement was a "license" authorized by the Patent Act, for it gave as one of its rationales that this type of settlement was nowhere authorized by the patent statute. ${ }^{42}$ Moreover, focusing on the legality of an exclusive license misses the key issue, the fact of a transfer of value from Brand to Generic. As one district court explained this point, "[i]f some particular transfer of money would be unlawful-for whatever reason-its unlawfulness is not cured merely because the value is transferred in the form of exclusive licenses instead of cash, irrespective of whether the grant of an exclusive license would otherwise be valid." 43

Summarizing, no-AG provisions are even more worrisome from an antitrust perspective than are reverse payments made in cash. No-AG provisions should be treated as a form of reverse payment, the magnitude of which must be estimated on a case-by-case basis. The Actavis Inference that a large and unexplained reverse payment is anticompetitive should apply to sufficiently valuable no-AG provisions.

\section{Pleading Issues}

Pleading standards for pay-for-delay cases must meet the procedural standards of the Supreme Court's Twombly decision, ${ }^{44}$ which assesses

41. 35 U.S.C. $\$ 261$ (2012) (patentee may grant an exclusive license).

42. FTC v. Actavis, Inc., 133 S. Ct. 2223, 2233 (2013).

43. In re Aggrenox Antitrust Litig., No. 14-MD-2516, 2015 U.S. Dist. LEXIS 35634, at *49 (D. Conn. Mar. 23, 2015); see also id. ("The statutory authority to grant exclusive licenses no more immunizes reverse-payment settlements that include them from antitrust scrutiny under Actavis than the statutory authority to use cash as legal tender immunizes reverse-payment settlements made in cash from such scrutiny.").

44. Bell Atl. Corp. v. Twombly, 550 U.S. 544, 558, 570 (2007) (concluding that complaint's "factual allegations must be sufficient to raise a right to relief above the 
specificity requirements, and also the substantive standards of Actavis, which require a "large" and "unexplained" payment in exchange for a delay in entry. Here, we consider standards that plaintiffs must meet if they intend to avail themselves of the Actavis Inference; we do not address what applicable standards should be if the plaintiffs have another plan to establish an anticompetitive payment for delay.

\section{Products and Services Furnished by the Branded Firm}

Often, the pleading issue arises in the context of noncash payments. As discussed above, most courts agree that the payment need not be in cash. 45 They are also sensitive to the fact that noncash payments are more difficult to evaluate than cash. This complication has presented several issues at the pleading stage.

If the noncash payment consists of products or services, then the associated cost to the branded firm (including the opportunity cost) must be alleged and eventually proven. In one case involving the drug Lidoderm, one component of value was easily alleged because the agreement required the brand to give $\$ 12$ million per month of the branded product to the generic, thus stipulating the value of the noncash payment. ${ }^{46}$ In any event, the court concluded, a noncash payment that takes the form of product involves "a simple transfer of a fungible product" and "calculating its value is straightforward." 47 As a result, a plaintiff who simply alleged the value of such a transfer survived dismissal on this issue. ${ }^{48}$

\section{Settlement of Unrelated Patent Litigation}

In other cases the payment may be more difficult to value. For example, if the payment takes the form of a settlement payment in unrelated patent litigation that is far off of its reasonable market value, then a plaintiff would have to place a value on that litigation in order to

speculative level," which requires more than a "sheer possibility that a defendant has acted unlawfully”); see also Ashcroft v. Iqbal, 556 U.S. 662 (2009).

45. See supra note 27 and accompanying text.

46. United Food \& Commercial Workers Local 1776 v. Teikoku Pharm. USA, Inc., No. 14-MD-02521, 2014 WL 6465235, at *12 (N.D. Cal. Nov. 17, 2014).

47. Id.

48. See also King Drug Co. of Florence v. Cephalon, Inc., No. 06-CV-1797, 2015 U.S. Dist. LEXIS 9545, at *63-69 (E.D. Pa. Jan. 28, 2015) (denying summary judgment, in case involving alleged services provided by the generic, after crediting opinion of plaintiffs' experts that the services were "unnecessary and unwanted"; not necessary for plaintiff to show that the services were mispriced, provided that they created a reasonable inference that they were paid for delay). 
plausibly allege that there was a payment for delay.49 Importantly, however, nothing in the standards for motions to dismiss prevent the ordinary tools of statistical and economic analysis from being used to estimate the value of the settlement of the litigation. This may require inferences to be drawn from experiences in similar (benchmark) markets, projections of market share or margins, and the like. Certainly, the motion to dismiss standard should not require more than ordinary summary judgment and trial rules require of expert testimony generally, and may make use of the same tools. ${ }^{50}$

\section{No-Authorized-Generic Deals}

As discussed above, most courts have recognized that no-AG provisions can constitute a payment for delay. ${ }^{51}$ Placing a value on no-AG agreements is more difficult than simply assessing a product price. To employ the Actavis Inference in the context of no-AG agreements, evaluation requires an estimate of the difference between branded profits with and without authorized generic entry. As noted previously, however, the parties negotiating these agreements appear to have little difficulty placing a value on them..$^{52}$ The district court in the Lidoderm case found it sufficient when a complaint cited an FTC study comparing market shares and margins in response to independent generic entry where an authorized generic was and was not present. The court concluded that "[t]hese calculations are not overly complicated, and they are plausible." 53

\section{Size of Payment Compared with Avoided Litigation Costs}

A further pleading issue, beyond the valuation of noncash payments, arises in the context of avoided litigation costs. Although a few courts have suggested the contrary, the Supreme Court does not require evidence of a payment of a particular size. Actavis requires only a payment in excess of the patentee's reasonably anticipated avoided

49. Courts have confronted this issue in In re Nexium (Esomeprazole) Antitrust Litig., No. 12-MD-02409, 2014 WL 4370333 (D. Mass. Sept. 4, 2014) (summary judgment); and In re Lipitor Antitrust Litig., No. 12-CV-2389, 2013 WL 4780496, at *26 (D.N.J. Sept. 5, 2013) (motion to dismiss).

50. See 2A PhILlip E. AREEDA \& HeRbert HovenKamp, ANTITRUST LAW 9397 (4th ed. 2014).

51. See supra Part III.B.

52. See supra notes $45-47$ and accompanying text.

53. United Food \& Commercial Workers Local 1776 v. Teikoku Pharma USA, Inc., No. 14-MD-02521, 2014 WL 6465235, at *12 (N.D. Cal. Nov. 17, 2014) (citing and discussing FDA, Generic Competition and Drug Prices, http://www.fda.gov/AboutFDA CentersOffices/OfficeofMedicalProductsandTobacco/CDER/ucm129385.htm). 
litigation costs to trigger the Actavis Inference. The Actavis dissent recited two estimates for litigation costs, ranging from $\$ 1.5$ million per side to $\$ 10$ million per suit, ${ }^{54}$ which provide useful guidance. So a plaintiff need not plead the precise or even a ballpark value of a no-AG or other noncash agreement; rather, it must provide a sufficient basis for believing that the cost to the branded firm exceeds that firm's anticipated litigation costs. A figure of $\$ 200$ million would be sufficient, but so would $\$ 20$ million. We thus question one district court's conclusion in Effexor $X R$ that "the non-monetary payment must be converted to a reliable estimate of its monetary value so that it may be analyzed against the Actavis factors." 55 Actavis never states that the value of the payment must be ascertained, but only that it must be shown to be above reasonably anticipated litigation costs to trigger the Actavis Inference. At the same time, the Effexor XR court was disturbed by the fact that the plaintiffs did not provide a basis for placing any value at all on the arrangement. However, the court also suggested that simply citing the Actavis dissent's figures would have been sufficient. ${ }^{56}$

One important takeaway from these decisions is that those drafting complaints should avail themselves of the enormous published literature from the FTC and elsewhere placing a value on such things as litigation costs, no-AG agreements, and other arrangements. While summary judgment may require more particularized proof specific to the case, citation of relevant, credible studies should be sufficient to satisfy the Twombly pleading threshold.

\section{Causation and Damages}

Unlike the government enforcement agencies, private plaintiffs must plead injury and indicate some reasonable basis for damages if they are seeking them. For the plaintiff seeking an injunction, an allegation of

54. FTC v. Actavis, Inc., 133 S. Ct. 2223, 2243-44 (2013) (Roberts, C.J., dissenting).

55. In re Effexor XR Antitrust Litig., No. 11-CV-5479, $2014 \mathrm{WL} 4988410$, at *20 (D.N.J. Oct. 6, 2014). The same district judge reached a similar conclusion in the Lipitor litigation. In re Lipitor Antitrust Litig., No. 12-CV-2389, 2013 WL 4780496, at *27 (D.N.J. Sept. 5, 2013) (dismissing complaint for failure to estimate of value of settlements of unrelated litigation alleged to be a payment for delay). For a contrary conclusion, see In re Aggrenox Antitrust Litig., No. 14-MD-2516, 2015 U.S. Dist. LEXIS 35634, at *47-48 (D. Conn. Mar. 23, 2015) ("shar[ing] the concerns expressed" in Effexor XR and Lipitor, but denying dismissal because "it is also clear that very precise and particularized estimates of fair value and anticipated litigation costs may require evidence in the exclusive possession of the defendants, as well as expert analysis, and that these issues are sufficiently factual to require discovery.").

56. In re Effexor, $2014 \mathrm{WL} 4988410$, at *22 ("[T] he Complaint could have alleged that a reliable foundation is what is set forth in Actavis. ..."). 
threatened harm is sufficient and should be satisfied by reasonable allegations that the settlement agreement is unlawful and that entry was delayed past the reasonably anticipated entry date. Indeed, to the extent that the injunction seeks only prospective relief, a precise but-for entry date need not be calculated at all. Once the settlement is found unlawful the court may simply dissolve the agreement and open the way to immediate entry.

If the plaintiff is seeking damages, however, calculating value is likely to require establishing a but-for entry date, or estimate of the date on which generic entry would have occurred had the pay-for-delay settlement not intervened. In some cases the but-for entry date could be almost immediately after the settlement. For example, the Lidoderm district judge credited the argument (on a motion to dismiss) that the generic would have been willing to risk entry immediately once it had received a favorable ruling on claim construction of the patent in question. ${ }^{57}$ In any event, estimating a but-for entry date is likely to be easiest in cases where a court has already declared a patent invalid or legal proceedings in a patent infringement suit have moved sufficiently far along to warrant the conclusion that a reasonable generic would have been willing to risk entry.

Causation issues also can arise if FDA approval has not yet occurred, for reasons unrelated to the patent dispute itself. If the first-filing generic had difficulties gaining FDA approval, the question naturally arises whether the settlement was likely to delay generic entry. However, even if the settling first-filing generic could not have entered earlier, due to lack of FDA approval, the settlement may still have had an anticompetitive effect, if the reverse-payment settlement delayed entry by other generic firms. These issues arose in the Nexium case, where the jury rejected causation on specific facts. 58

57. United Food, 2014 WL 6465235, at *15-16; see also King Drug Co. of Florence v. Cephalon, Inc., No. 06-CV-1797, 2015 U.S. Dist. LEXIS 9545, at *69-71 (E.D. Pa. Jan. 28, 2015) (plaintiffs created fact issue that generic would have entered at risk but for settlement).

58. See Memorandum in Support of Plaintiffs' Motion for Permanent Injunction, In re Nexium (Esomeprazole) Antitrust Litigation, No. 12-MD-02409 (D. Mass. Jan. 7, 2015); $c f$. In re Nexium Antitrust Litig., Nos. 14-1521, 14-1522, 2015 WL 265548, at *4 (1st Cir. Jan. 21,2015 ) (approving, on divided panel, certification of class action even though expert's methodology for proving causation and harm might have included a few class members who were not injured). 


\section{E. Other Issues}

Also important are collateral allegations that do not pertain directly to the pay-for-delay sequence. While the Actavis Inference does not require proof of patent invalidity or noninfringement, some cases directly involve such claims. For example, some cases contain independent allegations that the brand's patent was obtained by inequitable conduct or fraud, and that the improperly brought infringement suit was also monopolization or an attempt to monopolize under Section 2 of the Sherman Act. 59

Today it is clear that consumers have standing to bring Walker Process actions of this sort. ${ }^{60}$ Such a claim could yield damages quite aside from the existence of any pay-for-delay settlement. ${ }^{61}$ In addition, success on such a claim may provide evidence of a presumptive but-for entry date. For example, suppose that a branded firm whose primary patent expired in 2010 obtained a secondary patent lasting until 2020 but the latter patent was fraudulently obtained and unenforceable. One might readily conclude that one or more generic firms would have been able to enter in 2010 upon the expiry of the original patent.

\section{The ACtavis InfEREnCE With Multiple GENERIC ENTRANTS}

In the Actavis decision, Justice Breyer opened his opinion by focusing on a patent holder and a single alleged infringer: "Company A sues

59. See In re Effexor XR Antitrust Litig., No. 11-CV-5479, 2014 WL 4988410, at *26 (D.N.J. Oct. 6, 2014) (finding sufficient allegations of intent to commit fraud on the Patent Office to withstand motion to dismiss); FTC v. Cephalon, Inc., 36 F. Supp. 3d 527, 534-36 (E.D. Pa. 2014) (concluding that patentee had committed fraud on the Patent Office prior to entering settlement agreement); In re Lidoderm Antitrust Litig., 11 F. Supp. 3d 1344, 1345 (M.D.L. 2014) (noting assertion of sham litigation claim); King Drug Co. of Florence v. Cephalon, Inc., Nos. 06-CV-1797, 06-CV-1833, 06-CV-2768, 08-CV-2141, 2014 WL 982848, at *11 (E.D. Pa. Mar. 13, 2014) (discussing Walker Process claim accompanying reverse payment claim against parties to Provigil settlement); In re Lipitor Antitrust Litig., No. 12 CV-2389, 2013 WL 4780496, at *18-20 (D.N.J. Sept. 5, 2013) (noting allegations of Walker Process fraud in obtaining patent).

60. Ritz Camera \& Image, LLC v. SanDisk Corp., 700 F.3d 503, 508 (Fed. Cir. 2012); In re DDAVP Direct Purchaser Antitrust Litig., 585 F.3d 677, 690-91 (2d Cir. 2009). See generally Walker Process Equip., Inc. v. Food Mach. \& Chem. Corp., 382 U.S. 172 (1965) (noting that patent infringement lawsuit based on fraudulently obtained patent could constitute an antitrust violation).

61. For example, some decisions permit recovery of (trebled) litigation costs as antitrust damages for Walker Process claims. See Premier Elec. Constr. Co. v. Nat'l Elec. Contractors Ass'n, Inc., 814 F.2d 358, 373-74 (7th Cir. 1987); Kearney \& Trecker Corp. v. Cincinnati Milacron, Inc., 562 F.2d 365, 374 (6th Cir. 1977); 1 PHILlIP E. AREEDA \& HERBERT HOVENKAMP, ANTITRUST LAW If 205h (4th ed. 2013). 
Company B for patent infringement. The two companies settle under terms that require (1) Company $B$, the claimed infringer, not to produce the patented product until the patent's term expires, and (2) Company A, the patentee, to pay B many millions of dollars." 62

Despite this crisp and abstract framing, which focuses on just two firms, the Actavis case itself actually involved more than one generic entrant, as Justice Breyer recognized. ${ }^{63}$ As a matter of law, the Actavis Inference established by the Supreme Court clearly applies whether there is one generic entrant or multiple generic entrants.

Many pharmaceutical reverse payment antitrust cases involve the prospect of sequential entry by multiple generic suppliers. ${ }^{64}$ Typically, after the first-filing generic firm's 180-day period of exclusivity ends, additional generic firms enter the market before patent expiration. Indeed, most of the drugs that are currently the subject of reverse payment antitrust litigation have this feature. To illustrate, consider seven drugs discussed in Part II.A, analyzed there in the context of district court opinions that assessed alleged noncash payments for delay. ${ }^{65}$ For five of the seven, additional generic entrants were waiting in the wings following entry by the first filer. ${ }^{66}$ For the remaining two drugs,

62. FTC v. Actavis, Inc., 133 S. Ct. 2223, 2227 (2013).

63. Solvay, the manufacturer of AndroGel, faced multiple generic firms who had filed ANDAs seeking entry before patent expiration. Actavis was first, and therefore enjoyed the prospect of 180 -day exclusivity. (At that time, the firm was called Watson. Watson later acquired Actavis and changed its name to Actavis.) Paddock Laboratories also filed an ANDA, and partnered with a third firm, Par Pharmaceuticals, to share the benefits and costs of its challenge. As a later filer, Par/Paddock was stuck behind the Actavis exclusivity. Id. at 2229. Solvay sued the generic firms, which litigated the dispute for several years. For a description, see In re Androgel Antitrust Litig. II, 687 F. Supp. 2d 1371, 1374-75 (N.D. Ga. 2010). During the course of litigation, the FDA approved the Actavis ANDA. Shortly thereafter, Solvay entered the challenged settlements with Watson and Par/Paddock, with alleged payments exceeding $\$ 170$ million to Actavis and $\$ 72$ million to Par/Paddock. See Actavis, $133 \mathrm{~S}$. Ct. at 2229 (describing payments to Actavis for nine years between $\$ 19$ and $\$ 30$ million per year, $\$ 60$ million to Par, and $\$ 12$ million to Paddock).

64. Multiple entry can also occur without sequential entry. For example, for some drugs, there are multiple first filers that settle for entry on the same day. The case of multiple simultaneous entrants is in important respects similar to the monopoly/duopoly case. We do not separately model that case here.

65. The drugs are Effexor XR, Lamictal, Lidoderm, Lipitor, Loestrin, Nexium, and Niaspan. As to an eighth drug discussed in Part II.A, Aggrenox, the timing of multiple generic entry cannot be assessed using public information.

66. Effexor XR: First-filer Teva secured a July 2010 entry date; sixteen later filers were sued and settled, starting with IMPAX, which secured a June 2011 entry date. See In re Effexor XR Antitrust Litig., No. 11-CV-5479, 2014 WL 4988410, at *11, *12 \& n.13 (D.N.J. Oct. 6, 2014); Press Release, IMPAX Announces Final Settlement of Generic EFFEXOR XR Patent Suit (July 16, 2008). 
the first filer's settlement was set so late in the patent term that additional generic entry before patent expiration was infeasible. ${ }^{67}$

Lidoderm: First-filer Watson secured a September 2013 entry date. United Food \& Commercial Workers Local 1776 v. Teikoku Pharma USA, Inc., No. 14-MD-02521, 2014 WL 6465235 , at *5 (N.D. Cal. Nov. 17, 2014). At least three additional generics-Mylan, Noven, and TWI-filed Paragraph IV certifications and were sued. Mylan's ANDA (\#20-2346) predated the Watson settlement. Mylan secured a consent judgment of noninfringement on claim 1 of the single patent at suit. Consent Decree \& Order, Endo Pharm. v. Mylan Technologies, Inc., No. 11-CV-220 (D. Del. Oct. 4, 2013). As of December 2014, no additional generic entrants have been approved due to unrelated FDA approval delays. See Mylan Q3 2014 Analyst Call (Oct. 30, 2014).

Lipitor: First-filer Ranbaxy secured a November 2011 entry date. Later filer Teva was waiting in the wings to enter, but for Ranbaxy's 180-day eligibility. See New York Attorney General, Assurance of Discontinuance 7 (Feb. 12, 2014), http://www.ag.ny.gov/pdfs/AOD_Teva_Ranbaxy_Signed.pdf.

Nexium: First-filer Ranbaxy secured a May 2014 entry date. Later filer Teva secured the same date in a second settlement. In re Nexium (Esomeprazole) Antitrust Litig., $968 \mathrm{~F}$. Supp. 2d 367, 382-83 (D. Mass. 2013). The Teva date was, in practice, subject to a 180-delay thanks to Ranbaxy's exclusivity.

Niaspan: First-filer Barr (later acquired by Teva) secured a September 2013 entry date and launched at that point. In re Niaspan Antitrust Litigation, No. 13-MD-2460, $2014 \mathrm{WL}$ 4403848, at ${ }^{*} 6$ (E.D. Pa. Sept. 5, 2014). Suits against Lupin and Sun, among others, were filed and later dismissed. Lupin and Sun received approval in early 2014, shortly after expiration of the 180 days.

Androgel, the drug considered in Actavis, is a further example. At the time of the Androgel settlements, Actavis and Par/Paddock had agreed to staggered entry dates. See Solvay Settles Dispute with Par, Watson, Associated Press, Sept. 13, 2006 (noting August 2015 entry for Actavis, February 2016 entry for Par/Paddock); Brief in Opposition of Par/Paddock at App. 4a I 6, Actavis, 133 S. Ct. 2223 [hereinafter Brief in Opposition] (providing in settlement agreement for entry in February 2016 provided that Actavis entered with exclusivity in August 2015). Later, Actavis voluntarily relinquished its entitlement to the 180 days. Brief in Opposition at 10; see also In re Androgel Antitrust Litig. II, 687 F. Supp. 2d at 1377. As a consequence, Actavis and Par/Paddock ended up with the same entry date. See Second Amended Complaint for Injunctive and Other Equitable Relief If 65, FTC v. Watson Pharm., Inc., No. 09-CV-00955 (N.D. Ga. May 28, 2009) (alleging August 2015 entry date for both Actavis and Par/Paddock); Actavis, $133 \mathrm{~S}$. Ct. at 2229 ("The other generic manufacturers made roughly similar promises.").

67. For Lamictal and Loestrin, the first filer's entry date was six months prior to patent expiration, and the first filer anticipated launching with exclusivity, leaving other generics with the prospect of waiting until patent expiration.

Lamictal: First-filer Teva secured a July 2008 entry date, six months prior to patent expiration (as extended by pediatric exclusivity). In re Lamictal Direct Purchaser Antitrust Litig., 18 F. Supp. 3d 560, 561 (D.N.J. 2014); see also Letter from Gary Buehler, Dir. of Office of Generic Drugs, FDA, to Philip Erickson, Teva Pharms. USA (Aug. 30, 2006) (approving ANDA 76-388 with exclusivity).

Loestrin: First-filer Watson secured a January 2014 entry date, six months prior to patent expiration. In re Loestrin 24 Fe Antitrust Litig., No. 13-MD-2472, 2014 WL 4368924, at *4 (D.R.I. Sept. 4, 2014). Later filer Lupin was sued and settled for entry "around the same time" as patent expiration. Id. at * 5 . Watson subsequently forfeited its exclusivity for failing to receive tentative approval within thirty months. Letter from Robert West, Dep. Dir. of Office of Generic Drugs, FDA, to Janie M. Gwinn, Watson Labs., Inc. FDA (Sept. 1, 
Because multiple generic entry is so common, as courts apply the Actavis Inference, it is important to understand how the economic logic underpinning the Actavis Inference works in cases with more than one generic entrant.

In Activating Actavis, we developed and explained the economic logic behind the Actavis Inference by describing the incentive of a patent holder to pay a single potential entrant to delay its entry into the market. Our economic model analyzed the case in which entry would convert a monopoly into a duopoly, i.e., the case of a single generic entrant. Here we extend our economic model to include multiple generic entrants. Reflecting the 180-day exclusivity period rewarded to the first generic firm under the Hatch-Waxman Act, our model contemplates sequential entry: initially one generic firm enters, followed later by more.

Common sense and intuition suggest that the Actavis Inference is even more important with multiple generic entrants than with just one generic entrant. With multiple generic entrants, delaying generic entry will boost profits even more, and harm competition even more, than with just one generic entrant. As a result, pay-for-delay settlements are even more tempting for the settling parties and even more harmful to consumers.

We show here that common sense and intuition are firmly supported by cold economic logic and formal economic modeling. Along the way, we show that the challenge to the Actavis Inference made by Kobayashi, Wright, Ginsburg, and Tsai in their recent paper is flawed on multiple grounds. KWGT criticize the Supreme Court's decision in Actavis as well as challenging the economic basis for the Actavis Inference that the Court established. Much of what KWGT recommend is of no help to courts, since KWGT elaborate arguments made by the Actavis dissent but rejected by the Court. Other claims by KWGT are incorrect or contradict KWGT's own economic analysis.

\section{A. Sequential Generic Entry Under the Hatch-Waxman Act}

The Hatch-Waxman Act's provision of 180-day exclusivity to a firstfiling generic firm creates an important mechanism for staggered entry by multiple generics. ${ }^{68}$ In many instances, additional generics are blocked

2009) (approving ANDA 78-267). According to plaintiffs, its settlement guaranteed the 180 days by contract (to the extent within control of the parties). Direct Purchaser Consolidated Amended Complaint at 41-42, Loestrin 24 Fe Antitrust Litig., No. 13-2472 (D.R.I. Dec. 6, 2013).

68. In this paper, we assume basic familiarity with this and other features of the Hatch-Waxman Act. The Actavis decision itself provides a brief overview of the relevant 
from the market until 180 days after the first generic's entry. ${ }^{69}$ Due to this provision in the Hatch-Waxman Act, a settlement between a branded pharmaceutical firm and the first-filing generic firm effectively immunizes even a very weak patent from challenge for the period covered by the delayed entry agreement plus 180 days.

Settlement has a further consequence in the case of multiple entrants. A fully litigated declaration of patent invalidity would estop the branded firm from asserting its patent against other generics, so after 180 days other generics would be able to enter the market as well. ${ }^{70}$ This prospect of entry by a second (or third) generic makes it even more valuable to the branded firm to enter into a pay-for-delay settlement with the first-filing generic, because drug prices, and hence the branded firm's profits, fall further in response to subsequent generic entry than they do in response to the first generic entrant. ${ }^{71}$

\section{B. Economic Analysis with Subsequent Generic Entrants}

In Appendix A, we present two formal economic models in which Brand and Generic negotiate to settle their patent litigation. These models extend our earlier monopoly-duopoly model to include subsequent generic entry.

In both models, if the parties do not settle, then following litigation, we assume that if the Generic prevails in the patent litigation, additional generic firms enter the market 180 days after Generic enters. ${ }^{72}$ The models differ in the case of settlement. A settlement specifies the date at which Generic can enter the market and the size of a payment from

provisions of the Hatch-Waxman Act. For a more thorough discussion of the operation of the 180-day exclusivity period, see C. Scott Hemphill, Paying for Delay: Pharmaceutical Patent Settlement as a Regulatory Design Problem, 81 N.Y.U. L. REv. 1553 (2006).

69. See 21 U.S.C. $\$ 355(j)(5)(B)(i v)(2012)$. The Supreme Court described the process in Actavis, $133 \mathrm{~S}$. Ct. at 2228.

70. See Blonder-Tongue v. Univ. of Ill. Found., 402 U.S. 313, 330-34 (1971) (holding that a patentee whose patent is found invalid in fully and fairly litigated decision is collaterally estopped from claiming validity against a subsequent infringement defendant).

71. See C. Scott Hemphill \& Mark A. Lemley, Earning Exclusivity: Generic Drug Incentives and the Hatch-Waxman Act, 77 ANTITRUST L.J. 947, 953-54 (2011) (collecting evidence); FTC, PAY-For-Delay: How DRUG COMPANY PAY-OFFs COST CONSUMERS BILLIONS 8 (2010) (concluding that based on public information about drug launches that in a "mature" generic market, one year after the first generic enters, generic penetration is 90 percent and generic prices are 15 percent of the pre-entry branded price). In our model in Appendix A, this effect is captured by the term. Our model also reveals an additional benefit to the branded firm from settlement that is not present in the model with only a single generic entrant. This additional incentive, captured by the term, is independent of the agreed-upon entry date of the generic firm.

72. If Brand wins the litigation, we assume no generic entry takes place. 
Brand to Generic. In the first model, which we call our "180-day duopoly" model, in the case of a settlement, we assume that additional generic firms enter the market 180 days after Generic enters the market, even if this time occurs before patent expiration. In our second model, the "durable duopoly" model, there is no multiple entry until patent expiration-that is, the settlement might result in a durable duopoly. (Durable duopoly is the case studied by KWGT.)

We prove four main results, which hold in both models of multiple generics.

Proposition \#1 says that the combined incentive of Brand and Generic to settle to restrict competition is greater with multiple generic entrants than for a single generic entrant. Put differently, the additional combined profits (compared with litigation) from the settlement that maximizes profits without any antitrust limits are greater in the presence of multiple generic entrants.

Proposition \#2 says that if the settlement involves a payment greater than Brand's prospective litigation costs, the settlement reduces the period of time during which consumers benefit from competition involving multiple generic firms. ${ }^{73}$

Proposition \#3 says that relaxing the Actavis Inference by allowing payments greater than litigation costs would harm consumers and reduce total welfare.

These three propositions together provide strong economic support for the Actavis Inference in the presence of multiple generic entrants. Proposition \#1 warns us that antitrust limits are needed-even more with multiple generic entrants- to protect consumers from settlements that would otherwise prevent generic entry for some or all of the remaining lifetime of the patent.

Proposition \#2 implies that antitrust appropriately comes into play if the payment is greater than litigation costs. Such settlements restrict competition by shortening the period of multiple generic competition compared to litigation. Such settlements are therefore anticompetitive under the logic of the Actavis opinion, as they prevent competition or eliminate the risk of competition.

Settlements violate Sherman Act $\S 1$ if they restrict competition and injure consumers. Given restriction of competition is found in Proposition \#2, the remaining question is what the benchmark of comparison is for consumer welfare by which to judge injury to consumers. Under the

73. This reduction is relative to the expected period of multiple-generic competition under litigation. Such a payment also signals that the patent holder had doubts about whether the patent would be found valid and infringed if litigated. 
Actavis opinion consumers are injured if the settlement leads to lower welfare than under either of the following two benchmarks: ${ }^{74}$

Benchmark \#1. The welfare that consumers could expect from completing the litigation.

Benchmark \#2. The welfare that consumers could achieve in an alternative settlement that did not have a large payment, i.e., a payment exceeding the plaintiff's prospective litigation cost. ${ }^{75}$

The second benchmark is an application of the less restrictive alternatives test. ${ }^{76}$ Lower payments will come with earlier entry dates (in equilibrium) and are less restrictive of competition.

Proposition \#3 tells us that a less stringent rule than the Actavis Inference, such as an inference only triggered by even larger payments, would be worse for consumers. Furthermore, relaxing the Actavis Inference is a bad idea even if one uses the more forgiving total welfare standard rather than the consumer welfare standard embraced by the Supreme Court.

A corollary of Proposition \#3 is that if we observe the parties bargaining to a settlement involving a reverse payment in excess of prospective litigation costs, then this settlement has lower consumer and total welfare than any alternative settlement that they would actually reach if they were constrained to a payment equal to or less than these litigation costs. Thus any settlement with a large payment injures consumers using Benchmark \#2 and it therefore violates the antitrust laws.

Injuring consumers compared with Benchmark \#1 is not required to violate the antitrust laws, given that consumers are injured with respect to a reasonable alternative settlement under Benchmark \#2. Nonetheless it is still worth investigating if settlements with large payments will

74. See Actavis and Error Costs, supra note 8, at 4. The Court's opinion supports this approach. See id.

75. The alternative settlement used in Benchmark \#2 should be one that the parties would likely reach if the parties were constrained to lower reverse payments.

76. On the importance of less restrictive alternatives in antitrust litigation under the rule of reason, see 7 PHILLIP E. AREEDA \& HERBERT HOVENKAMP, ANTITRUST LAW If 1505 (3d ed. 2010); C. Scott Hemphill, Less Restrictive Alternatives in Antitrust and Constitutional Law (working paper 2015); see also King Drug Co. of Florence v. Cephalon, Inc., No. 06-CV-1797, 2015 U.S. Dist. LEXIS 9545, at *44, *53-54, *62 (E.D. Pa. Jan. 28, 2015) (identifying and applying the rule, drawn from standard rule of reason principles, that plaintiff has opportunity to demonstrate that defendants' conduct was not necessary to achieve the asserted pro-competitive objective). 
injure consumers relative to Benchmark \#1. We believe that they typically will, but we have been able to construct a theoretical counterexample in which consumers are better off than with Benchmark \#1. Our counterexample requires some rather extreme assumptions: (1) Brand has no bargaining power; (2) Brand gets nearly the entire market during the duopoly period; and (3) There is no increase in quantity between duopoly and free entry.

Our final proposition asserts that typically a settlement with a large reverse payment will also injure consumers compared with Benchmark \#1. More specifically: Propositions \#4a and \#4b say that settlements with payments larger than litigation costs reduce consumer welfare, relative to litigation, under the conditions that apply in practice. ${ }^{77}$

The basic intuition underlying our four propositions is the same as in the monopoly-duopoly model. A payment larger than litigation costs raises the question: why is the brand paying so much? In the monopolyduopoly model, the answer is that Brand is paying to avoid or eliminate duopoly competition. In the multiple generic model, the answer is that Brand is paying to avoid or eliminate competition from multiple generics.

Our analysis further reveals the danger that certain anticompetitive reverse payment settlements will not be caught using the Actavis Inference. This danger is not unique to the case of multiple generic entrants but occurs because the Actavis Inference, by construction, is favorable to antitrust defendants. The reason has to do with the bargaining dynamics of a branded drug maker.

The point is most easily seen in the basic monopoly-duopoly model. If Generic has all the bargaining power-that is, it retains all of the joint gains from settlement-and Brand has none, then a payment that equals litigation cost involves no payment for delay. Because Brand has no bargaining power, the most Brand can get from the settlement is what it could expect from litigation, so the agreed entry date under the settlement equals the expected entry date under litigation. Because Brand has the option to litigate, this is also the least that Brand will accept. Thus, if there are ten years left on the patent and Brand has a $90 \%$ chance of winning the lawsuit, it will pay an amount equal to its litigation cost and allow entry at nine years, which equals $90 \%$ of ten years. There is no payment for delay in such a settlement. If the settlement involved a payment from Brand to Generic greater than litigation cost, Brand would require some delay in competition beyond the nine years. Hence, payments in excess of litigation cost involve payment for delay.

77. See infra Appendix A. 
Suppose instead that Brand has significant bargaining power, as is likely in practice. In such a case, even a payment just equal to litigation cost would involve a payment for delay. The reason is that while the earliest entry date acceptable to Brand is nine years, given a payment equal to Brand's litigation cost, the latest entry date acceptable to Generic will be something more than nine years-slightly more than 9.2 years in an example discussed by KWGT. ${ }^{78}$ This difference in acceptable entry dates represents a bargaining range. If Brand and Generic split the difference, a version of equal bargaining power, they will agree to an entry date in between-slightly more than 9.1 years. This implies that even though the payment just equals Brand's prospective litigation cost, part of the payment is compensation for a delay of 0.1 years. It follows that payments somewhat less than litigation cost also involve some payment for delay. 79

This example illustrates that the Actavis Inference is not sufficiently aggressive to eliminate all anticompetitive settlements. In this context, the Inference essentially assumes that Brand has no bargaining power. This supports our view that antitrust plaintiffs should and do have the ability to challenge reverse payment patent settlements without relying on the Inference.

This analysis does not mean that the Actavis Inference is ineffective. What the Inference accomplishes is to identify and deter the worst anticompetitive settlements. It prevents Brand and Generic from choosing settlements with later entry dates and larger payments-from moving out along the "Ray of Delay," in the terminology of our earlier paper ${ }^{80}$-thereby injuring consumers by reducing competition.

In the context of multiple generic entry, the effects are more complex because multiple entry broadens the bargaining range, compared to the monopoly-duopoly model. (KWGT also observe an expansion of the bargaining range. ${ }^{81}$ ) We speak of a settlement being "minimally acceptable" to Brand (respectively Generic) if it yields Brand (Generic) profits at least as high as expected under litigation. For any given level of payment, the possibility of multiple entry means that Brand would find earlier entry minimally acceptable, compared to the monopoly-duopoly model. Generic would likewise find later entry minimally acceptable.

78. See KWGT, supra note 10 , at 91 fig. 2 .

79. See also Hemphill, supra note 68 , at $1594-95$ (identifying an allocative harm from settlement, where payment is less than Brand's avoided litigation cost, if Brand has significant bargaining power).

80. Actavis and Error Costs, supra note 8, at 6.

81. KWGT, supra note 10 , at 89 . 
If Brand has no bargaining power, it is constrained to enter into a minimally acceptable settlement. Thus, compared to the monopolyduopoly model, it will accept an earlier date for the first generic entrant. Even with zero Brand bargaining power, all the results discussed above, regarding lost competition, reduced welfare, and the bad consequences of a relaxation of the Actavis Inference, fully apply. Indeed, such anticompetitive settlements may occur even in the face of the Inference with relatively low payments at or below prospective litigation cost. In this further respect, the Inference is insufficiently stringent to identify all anticompetitive settlements. However, the higher the reverse payments the more anticompetitive the settlements will be, holding bargaining power and other factors constant.

If Brand has bargaining power, settlements at any given level of payment are worse for consumers than if Brand has no power. The results above all still apply when the Brand has bargaining power and in some respects are strengthened. With a payment equal to litigation cost, a Brand with substantial bargaining power will insist upon a delay (compared to litigation) in the entry of all generics, including the firm it is settling with. For this reason, when Brand has substantial bargaining power, consumer welfare and total welfare will surely become lower in settlement than in litigation even when the inequality conditions of Propositions \#4 and \#4a are not satisfied. The anticompetitive potential of settlements is exacerbated by the presence of multiple generics when Brand has bargaining power, because Generic's minimally acceptable settlement is later than in a duopoly-monopoly model, and Brand's bargaining power pushes Generic closer to its minimally acceptable settlement. ${ }^{82}$

\section{Critique of Paper by Kobayashi, Wright, Ginsburg, and Tsai}

KWGT state that in Actavis the Court infers "that reverse payments greater than anticipated litigation costs are likely to harm competition" and that " $[t]$ he single-entrant models provide analytical support for the Court's inference." 83 We agree. Where we part ways is in multiple entrant models (incidentally the actual setting of Actavis). In such cases, KWGT believe that the legal rule of Actavis-the Actavis Inference-is not well supported by economic analysis. Their conclusion contains three claims:

82. For related arguments, see Einer Elhauge \& Alex Krueger, Solving the Patent Settlement Puzzle, 91 TEX. L. REv. 283, 314 (2012); Hemphill, supra note 68, at 1588-94.

83. KWGT, supra note 10 , at 90. 
The analysis in this article, which incorporates a model that allows for multiple entrants under Hatch-Waxman, shows such a rule will deem some welfare increasing settlements anticompetitive, encourage litigants to use other, potentially more inefficient means to settle, and increase the costs of dynamic Type I errors. ${ }^{84}$

We show below that each of these three claims is either incorrect, inconsistent with KWGT's own model, or irrelevant to a faithful implementation of the Court's opinion in Actavis. ${ }^{85}$

KWGT's own economic analysis confirms that in the absence of antitrust limits (or under the Actavis dissenters' scope of the patent test), Brand and Generic will have the mutual incentive to agree to delay Generic's entry into the market until the expiration of the patent, denying consumers any chance of enjoying the benefits of generic competition until the patent expires. This is exactly the incentive of the parties to move out the Ray of Delay that we described in Actavis and Error Costs. ${ }^{86}$ This incentive is illustrated by some early pay-for-delay settlements reached before parties became wary of antitrust liability, ${ }^{87}$ and also by some more recent settlements. ${ }^{88}$ Furthermore, KWGT's own economic model supports a more stringent approach to reverse payment settlements than provided by the Actavis Inference. As a result, there is a striking internal contradiction between the results found in KWGT's economic model and their policy conclusions.

As a preface for what follows, we note that all of the economic examples used by KWGT in their article are special cases of the durable duopoly model presented in Appendix A to this article. As a result, the three propositions discussed above and proven in Appendix A with respect to both of our models, also apply to all of KWGT's numerical examples. We now discuss KWGT's three claims.

84. Id. at 95 .

85. Our statements below should be understood to be made in the context of the KWGT examples and that of the models in our Appendix. As a result, some statements are starker than we would necessarily make outside the context of these economic models.

86. Actavis and Error Costs, supra note 8, at 6.

87. See, e.g., In re Ciprofloxacin Hydrochloride Antitrust Litig., 363 F. Supp. 2d 514, 519-20 (E.D.N.Y. 2005).

88. For example, the Lamictal and Loestrin settlements discussed above feature entry only in the last six months of the patent term, leaving just enough space for the first-filing generic to exercise exclusivity before patent expiration. For other drugs, the settlement date is timed to correspond to the effective end of the drug product's life due to efforts to switch patients to a new drug prior to generic entry. 


\section{KWGT Claim \#1: The Actavis Inference "will deem some welfare increasing settlements anticompetitive."}

Is Claim \#1 a problem for the Actavis Inference? KWGT certainly suggest as much, but as we now show, it is not.

If Claim \#1 is referring to consumer welfare, ${ }^{89}$ the standard used by the Actavis Court, then the claim flatly contradicts one of KWGT's own findings. In particular, when KWGT analyze the case of reverse payments with multiple generic entrants, ${ }^{90}$ they conclude: "Therefore, all feasible settlements, including those in which there is no reverse payment, generate consumer welfare that is lower than the expected welfare net of litigation costs that would be produced through litigation." 91

Regardless of whether Claim \#1 refers to total welfare or consumer welfare, Claim \#1 does not undermine the Actavis Inference. What does it mean that the Actavis Inference "will deem some welfare increasing settlements anticompetitive"? At most, it means that some feasible welfare increasing hypothetical settlements are banned by the Actavis Inference. ${ }^{92}$ But, the question is not whether feasible settlements that would improve welfare are prevented by the Actavis Inference. The question is whether desirable settlements that would actually be chosen in equilibrium are prevented by the Actavis Inference. The distinction between feasible outcomes and actual equilibrium outcomes is fundamental to neoclassical economic analysis, yet KWGT fail to make this distinction when they state their conclusion. ${ }^{93}$ This error is fatal to their critique of the Actavis Inference. ${ }^{94}$

89. See KWGT, supra note 10 , at $\mathbf{9 0}$ (asserting that a litigation cost benchmark would not "encourage settlements that would increase consumer welfare"); see also Joshua D. Wright, Comm'r, Fed. Trade Comm'n, Antitrust Analysis of Reverse Payment Settlements After Actavis: Three Questions and Proposed Answers (Oct. 10, 2014) (on file with authors) (making a closely related claim by reference to consumer welfare).

90. KWGT, supra note 10 , at $91-93$.

91. Id. at 93. Based on this statement, the KWGT analysis actually justifies a stronger version of the Actavis Inference, one that would apply to reverse payments smaller than litigation costs.

92. We follow KWGT here and refer to settlements that are preferred to litigation by both Brand and Generic as "feasible" settlements. In the economics literature, including the literature on bargaining and negotiations, this concept is referred to as "individually rational."

93. In Actavis and Error Costs, we made a similar critique of a recent paper by Harris, Murphy, Willig and Wright, who make a similar point to KWGT's. See Barry C. Harris, Kevin M. Murphy, Robert D. Willig \& Matthew B. Wright, Activating Actavis: A More Complete Story, ANTITRUST, Spring 2014, at 83 [hereinafter HMWW]. Both HMWW and KWGT are premised on an expansion of the parties' settlement range, and both criticize the Actavis Inference for banning hypothetical settlements that would not actually be equilibrium settlements if the Actavis Inference were abandoned. The odd thing about 
Propositions \#2 and \#3 show that when the reverse payment exceeds the Brand's prospective litigation costs, then the settlement is anticompetitive under Benchmark \#2 in Actavis. Moreover, Proposition \#3 shows that if the Actavis Inference were weakened, or eliminated, then the parties would choose settlements with lower consumer and total welfare in our models, and hence in the KWGT model as well. ${ }^{95}$ The reason is that allowing a larger reverse payment leads to an equilibrium settlement with later generic entry, which harms consumers and reduces total welfare; in the limit if all reverse payments are allowed, then the equilibrium settlement will delay competition until the patent expires. ${ }^{96}$ Thus, once we properly restrict attention to equilibrium settlements, it becomes clear that the presence of multiple generic entrants does not provide a reason to weaken or eliminate the Actavis Inference, regardless of whether consumer welfare or total welfare is the antitrust goal.

\section{KWGT Claim \#2: The Actavis Inference will "encourage litigants to use other, potentially more inefficient means to settle."}

This claim is a bare assertion, which makes its first appearance in the final sentence of the KWGT paper. The KWGT economic model does not analyze or mention "inefficient means to settle," and we are unable to find any arguments or facts in the KWGT paper that address this point or support this claim. Nonetheless, we pause to address this concern.

If the Actavis Inference applied only to cash settlements, as a few district courts have mistakenly held (see Part III above), then Brand and Generic would indeed be tempted to use noncash payments to transfer

KWGT making this mistake is that they do distinguish between feasible and equilibrium settlements in much of their analysis, yet they fail to do so in their policy conclusions.

94. By contrast, our model does not support the conclusion that all feasible settlements reduce consumer welfare.

95. These propositions therefore refute KWGT"s claim that "using litigation cost as an indicator of an anticompetitive settlement would [not] ... encourage settlements that would increase consumer welfare." KWGT, supra note 10, at 90. Abandoning the Actavis Inference would lead to equilibrium settlements with lower consumer welfare and total welfare than ones that would obtain under the Actavis Inference.

96. In fact KWGT state exactly this fact about equilibrium settlements in the course of their analysis: "If there are no legal constraints upon settlement, then the multiple entry model predicts a set of equilibrium settlements that do not allow early entry and in which reverse payments $X$ are 1.5 to more than 18 times the Brand's litigation costs." KWGT Working Paper, supra note 10 , at 12. All such settlements reduce consumer and total welfare with respect to both Benchmark \#1 and Benchmark \#2. In their conclusions, however, KWGT focus on feasible and not equilibrium settlements and suggest that it is lamentable that the Actavis Inference does not permit some hypothetically desirable settlements even though these settlements would not arise in equilibrium if the Actavis Inference were abandoned. 
value from Brand to Generic. Certainly these noncash means of transferring value could be inefficient. For example, Brand might issue a license to produce another drug on very favorable terms to Generic, even though Generic is not the most capable firm to make and sell that drug. The inefficiencies caused by these noncash transfers of value could well compound the anticompetitive inefficiencies, identified in Propositions \#2 and \#3, associated with large and unexplained cash payments.

The obvious way to avoid encouraging firms to "use other, potentially more inefficient means to settle" is to apply the Actavis Inference to all forms of consideration, not just cash, as we have explained here and previously. Here again, the economic analysis warns against a cramped or narrow interpretation of the Actavis Inference, the opposite of what KWGT advocate.

\section{KWGT Claim \#3: The Actavis Inference will "increase the costs of dynamic Type I [false condemnation] errors."}

This claim, like the first claim, is flatly inconsistent with KWGT's own economic analysis. As we noted above, in their model of multiple generic entry, KWGT conclude that "all feasible settlements, including those in which there is no reverse payment, generate consumer welfare that is lower than the expected welfare net of litigation costs that would be produced through litigation." 97 This statement implies that the Actavis Inference cannot lead to any false antitrust condemnations in their model according to their own analysis. Since all feasible settlements harm consumers, any settlement prevented by the Actavis Inference also would have harmed consumers. Stopping such a settlement is not an error, but rather the correct outcome under antitrust law, under the consumer welfare standard employed by the Actavis Court.

Furthermore, we have shown that KWGT's Claim \#3 is false in our more general economic model. Our Propositions \#2 and \#3 establishes that in our models (and thus in the KWGT model) the Actavis Inference will not generate any false antitrust condemnations. In the models, any settlement with a reverse payment in excess of litigation cost is indeed anticompetitive. Brand will only pay more than its litigation cost if doing so reduces the period of time during which consumers benefit from competition by multiple generic firms. In addition, our Proposition \#3 shows that weakening the Actavis Inference would lead to outcomes that are worse for consumers.

97. KWGT, supra note 10 , at 93. 


\section{The Role of Patent Validity As a SubStitute for the Actavis INFERENCE}

We now discuss the role of determinations of patent validity (or infringement ${ }^{98}$ ) in the antitrust assessment of the legality of reverse payment settlements. The Supreme Court clearly stated that "it is normally not necessary to litigate patent validity to answer the antitrust question." 99 Nonetheless, trial courts handling these antitrust cases will continue to be faced with evidence and arguments regarding patent validity or invalidity. Perhaps the starkest instances arise in antitrust cases where, subsequent to the reverse-payment settlement in question, but prior to the resolution of the antitrust case, the relevant patent is litigated and found to be either valid or invalid. For example, in the Cipro case, the patent was subsequently found valid, 100 and in the Provigil case the patent was later found invalid. ${ }^{101} \mathrm{~A}$ second situation arises if the antitrust court is asked to relitigate the patent case to assess its likely outcome, an unappetizing task disparaged as "turducken" by one court of appeals. ${ }^{102}$

Our main message here is straightforward: the correct antitrust analysis must be based on what was reasonably known to the parties about patent validity and infringement at the time they entered into their settlement. Stated differently, the antitrust analysis of a reverse-payment settlement should be made on an ex ante basis, as of the date of the settlement itself. A subsequent finding of patent invalidity does not imply that there was an antitrust violation, regardless of the presence or size of a reverse payment. Nor does a subsequent finding of patent infringement imply there was no antitrust violation despite a large and unexplained reverse payment. ${ }^{103}$

98. Our analysis in this Part generally applies to noninfringement, but we focus on validity for simplicity.

99. Actavis, $133 \mathrm{~S}$. Ct. at 2236.

100. In re Ciprofloxacin Hydrochloride Antitrust Litig., 261 F. Supp. 188, 197 (E.D.N.Y. 2003) (reporting unsuccessful post-settlement challenges to the patent including, inter alia, Bayer AG v. Schein Pharm., Inc., 301 F.3d 1306 (Fed. Cir. 2002)).

101. Apotex, Inc. v. Cephalon, Inc., No. 06-CV-2768, 2011 WL 6090696 (E.D. Pa. 2011), affd, 500 F. App'x 959 (Fed. Cir. 2013) (holding patent invalid and unenforceable, by same judge considering antitrust challenges to the settlement); see also In re Tamoxifen Citrate Antitrust Litig., 466 F.3d 187, 193 (2d Cir. 2005) (discussing instance where patent was invalidated by district court before settlement).

102. FTC v. Watson Pharm. Inc., 677 F.3d 1298, 1315 (11th Cir. 2012), rev'd on other grounds, Actavis, 133 S. Ct. 2223 (2013).

103. In Appendix B, we develop this point further, presenting an error-cost analysis of the Actavis Inference. As explained there, KWGT's error-cost analysis is fundamentally 
The Supreme Court adopted an ex ante approach in Actavis, which held that settling by paying to avoid the risk of competition, i.e., the risk of losing the patent case, is an antitrust violation. ${ }^{104}$ That risk is assessed at the time of the settlement; it would make no sense to evaluate such "risk" after the patent has been found valid or invalid. The very notion of "risk" here is an ex ante concept.

The best information the antitrust court has regarding the parties' ex ante beliefs about patent validity and infringement is likely to come from the terms of the agreement they reached. ${ }^{105} \mathrm{~A}$ large and unexplained payment is a strong signal that the patent holder had substantial doubts that it would win the underlying patent litigation. As put by the Court: "In a word, the size of the unexplained reverse payment can provide a workable surrogate for a patent's weakness, all without forcing a court to conduct a detailed exploration of the validity of the patent itself." 106 Moreover, as we noted in Activating Actavis, even a reliable determination that a patentee was likely to win its patent case does not answer the liability question, since a patentee may make a large payment to eliminate even a small probability of losing its case. 107

To illustrate why the antitrust analysis of patent settlements must be done on an ex ante basis, consider a garden variety patent license in which Firm A licenses its patent to its sole rival, Firm B. Under this license, Firm B pays running royalties to Firm A based on the number of units Firm B produces. The patent license raises Firm B's marginal costs and thus raises the prices charged by both firms to consumers. Suppose that Firm A's patent is subsequently found to be invalid. Unquestionably, the patent license led to higher prices, which harmed consumers. Unquestionably, Firm A derived benefits from a patent that was later found invalid. Yet it would be a mistake to conclude that the patent license violated antitrust law. To do so would open up most patent licenses to subsequent antitrust challenge, a highly undesirable outcome

flawed, since it starts from an incorrect notion of what constitute Type I and Type II errors in the antitrust assessment of a patent settlement.

104. The Court wrote that settling "to prevent the risk of competition" is "the relevant anti-competitive harm." Actavis, 133 S. Ct. at 2236. The European Court of Justice has also adopted an ex ante approach, writing that "the anti-competitive nature of [AstraZeneca's] acts must be evaluated at the time those acts were committed." AstraZeneca v. Commission, Case C-45710 P, December 6, 2012.

105. Information about patent strength known to the parties at the time of settlement, such as a prior judicial determination of validity or internal analyses identifying the weakness of the patent, might be a useful additional source of inference for the factfinder in cases where the facts evincing payment are ambiguous.

106. Actavis, 133 S. Ct. at 2236-37.

107. Activating Actavis, supra note 7, at 19. 
and one that is obviously contrary to antitrust law. 108 The only exception would be one where the patentee knew from the onset that the patent was invalid. ${ }^{109}$

The antitrust analysis of this garden variety license is done on an $e x$ ante basis, based on the information available to Firm $A$ and Firm $B$ when they signed the license. Presumably, Firm B only agreed to pay running royalties to Firm A because Firm $B$ believed there was some chance that Firm A would win if Firm A sued Firm B for patent infringement. Indeed, we would expect the negotiated royalty rate to reflect the strength of Firm A's patent. There is no basis to believe that Firm B paid "too high" a running royalty rate, and thus no basis to believe that the license harmed consumers. A subsequent determination that the patent is invalid does not change the proper, ex ante, antitrust analysis of the license. This same principle applies to reverse-payment settlements evaluated using the Actavis Inference.

There is an important lesson here for courts. The "turducken" approach of litigating the patent is not just costly, but largely beside the point when determining whether a reverse payment settlement violates the antitrust laws. The antitrust question has to do with whether competition was likely to have been reduced by the settlement, based on the information available to the parties at the time they settled their patent litigation. Relying instead on subsequent patent validity findings carries a heavy risk of hindsight bias.

\section{CONCLUSION}

We believe that our discussion has made several propositions clear.

First, nothing in either the Actavis decision or common sense indicates that noncash payments should be immunized from the Actavis Inference. To immunize such payments would completely undermine the Supreme Court's ruling. To be sure, noncash payments might sometimes be more difficult to evaluate, but federal judges have considerable experience in placing value on goods or services other than cash.

Second, no-authorized-generic provisions are a noncash form of value transfer that should count just as much as cash in determining the existence of a payment for delay. Indeed, to the extent that a no-AG provision differs from a cash payment, it is more anticompetitive. The

108. See Valley Drug Co. v. Geneva Pharm., Inc., 344 F.3d 1294, 1306-07 (11th Cir. 2003) (pay-for-delay settlement not unlawful per se simply because patent in question was subsequently found invalid: "We hold that the mere subsequent invalidity of the patent does not render the patent irrelevant to the appropriate antitrust analysis.").

109. Id. at $1307-09$. 
cash payment is simply a wealth transfer from the brand to the generic, while the no-AG provision operates as an additional anticompetitive market division.

Third, the Actavis Inference is at least as important when there are multiple generic entrants than when there is just a single generic entrant. This comports with common sense, and we have established this conclusion in a suitable economic model.

Fourth, litigating the patent is not only costly and unnecessary for the antitrust case, but largely beside the point and carries with it a substantial risk of hindsight bias. A large reverse payment is a surer sign of antitrust violation than a finding of patent invalidity. And, a finding of patent validity should not immunize the parties from antitrust violation.

Finally, our analysis indicates that the Actavis Inference is not the only way for a plaintiff to prove its case. The Actavis Inference will fail to capture some anticompetitive pay-for-delay agreements with payments less than anticipated litigation costs. This indicates that plaintiffs should be given the opportunity to establish through other means that a patent settlement is anticompetitive even if the Actavis Inference does not apply.

This conclusion is consistent the Actavis decision. Nothing in the decision immunizes from antitrust scrutiny settlements involving payment less than anticipated litigation costs. An antitrust challenge to such a settlement could succeed, without the benefit of the Actavis Inference, if the antitrust plaintiff is able to establish through other means that the settlement led to a delay in generic entry, and thus is anticompetitive. In other words, the Actavis decision did not create a safe harbor for settlements involving reverse payments smaller than anticipated litigation costs.

\section{APPENDIX A: ECONOMIC MODEL WITH MULTIPLE GENERIC ENTRANTS}

We denote the Brand by $B$ and the Generic, a first ANDA filer, by $G$. The remaining patent lifetime is $T$. For simplicity, we assume no time discounting. Brand places a probability $P$ on winning the patent litigation, i.e., that the patent will be found valid and infringed. Both Brand and Generic are assumed to be risk neutral. The exclusivity period for the first ANDA filer is denoted by $H$ (for half-year). Generic receives this exclusivity period if it litigates and wins, or if it settles.

Monopoly profits for Brand are denoted by $M_{B}$. Duopoly profits for Brand are denoted by $D_{B}$. Profits for Brand following multiple generic entry, which we refer to as "free entry," are denoted by $F_{B}$. Duopoly 
profits for Generic are $D_{G}$. Profits for Generic following multiple generic entry are denoted by $F_{G}$. All profit and consumer surplus measures are flows per unit time. We assume that the combined profits of Brand and Generic are higher under monopoly than duopoly, and higher under duopoly than under free entry: $M_{B}>\left(D_{B}+D_{G}\right)>\left(F_{B}+F_{G}\right)$.

Consumer surplus is higher under free entry, $F_{S}$, than under duopoly, $D_{S}$, and higher under duopoly than under monopoly, $M_{S}$, i.e., $F_{S}>D_{S}>M_{S}$. Total welfare, i.e., profits plus consumer surplus, is higher under free entry than under duopoly, and higher under duopoly than under monopoly.

Brand and Generic can settle or litigate. Litigation costs for Brand and Generic are $C_{B}$ and $C_{G}$. A settlement involves two parameters: the entry date $E$ for Generic and a reverse payment $X$ made by Brand to Generic. ${ }^{110}$ Since we are interested in the impact of allowing for multiple generic entry, we look at settlements that leave sufficient time for multiple generic entry to occur. This requires that $E+H<T$. If $E>T-$ $H$ there is no time prior to patent expiration for entry by other generics, so the monopoly-duopoly model and analysis apply.

\section{SETTLEMENT $[E, X]$ WITH MULTIPLE GENERIC ENTRANTS: 180-DAY DUOPOLY}

In this section we present and analyze our 180-day duopoly model of multiple generic entry in which we assume that Generic receives the exclusivity period $H$ following a settlement, with additional generic firms entering the market after that exclusivity period ends. In practice, in many or even most cases, the assumption that further generic entry will occur following a settlement and the 180-day exclusivity period is empirically correct. For example, in five of the seven drugs with pay-fordelay litigation discussed in Part IV, there were additional entrants poised to enter, prior to patent expiration, following the expiration of the 180 days. In the remaining two, the first filer's entry date was 180 days prior to patent expiration, and no additional pre-expiration entry was possible.

This is not the assumption made by KWGT. They assume instead that there is no additional generic entry prior to patent expiration following a settlement, even if there is time left on the patent for such entry to occur after the end of the 180 days. Instead, they assume there is

110 The reverse payment $X$ in our model should be interpreted as net of any consideration flowing from Generic to Brand. In the language of Actavis, $X \cdot C_{B}$ is the "unexplained" payment from Brand to Generic. 
durable duopoly. We consider that situation in our durable duopoly model subsequently.

Table 1 gives the expected time spent in monopoly, duopoly, and free entry during the patent period under litigation and under the settlement $[E, X]$ in the 180 -day duopoly model.

\begin{tabular}{|c|c|c|}
\hline $\begin{array}{c}\text { Table 1: 180-day } \\
\text { Duopoly Model }\end{array}$ & \multicolumn{2}{|c|}{ Expected Period of Time } \\
\hline & Litigation & Settlement \\
\hline Monopoly & $P T$ & $E$ \\
\hline Duopoly & $(1-P) H$ & $H$ \\
\hline Free entry & $T-P T-(1-P) H=$ \\
$(1-P)(T-H)$ & $T \cdot E-H$ \\
\hline
\end{tabular}

\section{Combined Profits from Eliminating Competition}

If Brand and Generic bargain efficiently without any antitrust constraints other than the scope-of-the-patent test, they will select $E$ to maximize their combined profits, with $X$ determining how those profits are split between Brand and Generic. This implies that $E=T$, so generic entry does not occur prior to the expiration of the patent. This yields combined profits of $T M_{B}$. Litigating yields combined profits of:

$$
P T M_{B}+(1-P) H\left(D_{B}+D_{G}\right)+(1-P)(T-H)\left(F_{B}+F_{G}\right)-C_{B}-C_{G} .
$$

The additional profits available from settling and preventing generic entry for the lifetime of the patent are the difference between these two expressions, which is equal to

$$
(1-P) T\left(M_{B}-D_{B}-D_{G}\right)+(1-P)(T-H)\left(D_{B}+D_{G}-F_{B}-F_{G}\right)+C_{B}+C_{G} .
$$

The first term represents the extra profits from monopoly rather than duopoly, in the event that the patent does not hold up in litigation. The second term reflects the extra profits from duopoly rather than free entry, after the 180-day exclusivity period ends, in the event that the patent does not hold up in litigation. The final two terms are the savings on litigation costs from settling. The first term is unchanged from the monopoly to duopoly model. The second term only arises with multiple generic entrants, which lowers the profits to Brand and Generic in comparison with duopoly. Since this term is positive, we have:

Proposition \#1: The incentives of Brand and Generic to enter into an anticompetitive settlement delaying generic entry are greater with multiple generic entrants than with one generic entrant. 
Brand Payoff from Settlement vs. Litigation

Brand's payoff from settling on terms $[E, X]$ is

$E M_{B}+H D_{B}+(T-E-H) F_{B}-X$. Brand's expected payoff from

litigating is $P T M_{B}+(1-P)\left[H D_{B}+(T-H) F_{B}\right]-C_{B}$. If we observe a settlement, we may reasonably infer that it was better for Brand than litigating, so we can infer that

$$
E M_{B}+H D_{B}+(T-E-H) F_{B}-X>P T M_{B}+(1-P)\left[H D_{B}+(T-H) F_{B}\right]-C_{B} .
$$

Simplifying, this inequality can be written as

$$
(E-P T)\left(M_{B}-F_{B}\right)+P H\left(D_{B}-F_{B}\right)>X-C_{B} .
$$

The first term on the left-hand side represents the expected value to Brand of delaying entry. The expected length of the delay is $E-P T$ and the value to Brand of delay is $M_{B}-F_{B}$. This is the value of delay because a later entry date does not affect the length $H$ of the duopoly period. As shown in Table 1, later entry prolongs the initial monopoly phase and shrinks the final, free-entry phase.

The second term of the left-hand side represents an additional value to Brand of settling. So far as we are aware, this effect has not previously been identified. Under settlement, Brand will surely benefit from the partial protection associated with duopoly rather than free entry. This protection has value $H\left(D_{B}-F_{B}\right)$. Under litigation, Brand will only receive this partial protection if it loses the patent litigation. In expected value terms, this partial protection is worth $(1-P) H\left(D_{B}-F_{B}\right)$. Settlement gives an additional value equal to the difference between these two terms, namely $P H\left(D_{B}-F_{B}\right) .111$

The right-hand side, $X-C_{B}$, is the extra out-of-pocket cost of settlement vs. litigation.

111. Another way to understand this non-intuitive term is to ask how increasing the exclusivity period, $H$, affects Brand's incentive to settle. If Brand settles, longer exclusivity is valuable to Brand for sure. However, if Brand settles, longer exclusivity is valuable to Brand only if it loses the litigation. Increasing $H$ thus tilts Brand toward settling. 
Comparison with Monopoly to Duopoly Model

In our previous model, there was no additional entry following the exclusivity period, so $F_{B}=D_{B}$. Making this substitution, the inequality above becomes $(E-P T)\left(M_{B}-D_{B}\right)>X-C_{B}$.

The prospect of multiple generic entry increases the benefit to Brand of a settlement that delays entry, for two reasons. First, delaying entry gives Brand extra profits of $(E-P T)\left(M_{B}-F_{B}\right)$, which is greater than $(E-P T)\left(M_{B}-D_{B}\right)$. This reflects the additional harm to competition associated with delayed entry in the case of multiple generic entry. Second, settlement allows Brand to receive duopoly protection with certainty rather than just when it loses the patent litigation. This produces an extra settlement value of $\operatorname{PH}\left(D_{B}-F_{B}\right)$. Note that this value is independent of the entry date $E$.

Actavis Inference with Multiple Generic Entrants: Large Payments Imply Less Competition from Multiple Generic Entrants

We now show that the Brand will only be willing to make a reverse payment in excess of its prospective litigation cost if the settlement results in less competition (in expectation) from multiple generics. Thus, in the multiple entry model, large reverse payments continue to be payments to delay competition in that sense.

Under the settlement, consumers benefit from multiple generic competitors for a time period of length $T-E-H$. Under litigation consumers benefit from multiple generic competitors for an expected time period of $(1-P)(T-H)$. The settlement reduces the expected amount of time during which consumers benefit from multiple generic competitors if and only if $T-E-H<(1-P)(T-H)$. This can be written as

$$
P T-E<P H \text {. }
$$

Suppose we observe a settlement with a reverse payment in excess of the Brand's litigation costs, $X>C_{B}$. Using inequality (1) above, this implies

$$
(E-P T)\left(M_{B}-F_{B}\right)+P H\left(D_{B}-F_{B}\right)>0 .
$$

If $E>P T$, then $P T-E<0$ which implies that inequality (2) is satisfied. Alternatively if $E<P T$, then we can rewrite inequality (3) as $P H\left(D_{B}-F_{B}\right)>(P T-E)\left(M_{B}-F_{B}\right)$, where all of the terms in this expression are positive. This in turn can be rewritten as $\frac{P H}{P T-E}>\frac{M_{B}-F_{B}}{D_{B}-F_{B}}$. 
The right-hand side is greater than unity. Therefore we must have $P H>P T-E$, which is exactly inequality (2) that we were seeking to show. Therefore, we have established:

Proposition \#2: Any settlement with a reverse payment in excess of Brand's litigation costs must restrict competition in the sense of reducing the expected period of time during which consumers benefit from competition by multiple generic entrants.

\section{Allowing Larger Reverse Payments Harms Consumers and Total Welfare}

Above we showed in this model that Brand would not make payments in excess of its litigation costs other than to limit competition from multiple generics. Here we study the effect of payment size upon consumer welfare. In particular, we show that consumers are harmed if we raise the size of the allowable reverse payment above $C_{B}$.

Let $X_{\max }$ be the maximum reverse payment that does not trigger the Actavis Inference. Our monopoly to duopoly model suggested that $X_{\max }$ should be set at the level of Brand's litigation cost, $C_{B}$. This also is what Justice Breyer concluded in the Actavis decision.

We use the concept of monotonic bargaining from Edlin and Reichelstein (1996). ${ }^{112}$ Monotonic bargaining means that if the bargaining space increases, neither party winds up with less profit under the bargaining outcome. We now prove:

Proposition \#3: If settlement bargaining between Brand and Generic is efficient and monotonic, and if the legal rule $X_{\max }=C_{B}$ leads to entry before $\mathrm{T}$, then consumer welfare and total welfare will both be lower for any legal rule $X_{\max }>C_{B}$ that relaxes the Actavis Inference than for the rule $X_{\max }=C_{B}$.

Proof. An increase in $X_{\max }$ above $C_{B}$ increases the set of feasible settlements, so with monotonic bargaining, neither party can end up with lower profit than they would if $X_{\max }=C_{B}$.

112. Aaron Edlin \& Stefan Reichelstein, Holdups, Standard Breach Remedies, and Optimal Investment, 86 AM. ECON. REV. 478, 482 (1996) (defining a bargaining sharing rule as monotonic if "the payoff each party receives from bargaining is (weakly) increasing in the size of the renegotiation surplus"). In the context of this paper, the legal rule defines a profit possibility frontier and space of firm profits that weakly exceed firm profits under litigation. An increase in $X_{\max }$ enlarges this bargaining space. 
Let $\left[E^{*}, X^{*}\right]$ be the entry date and reverse payment that Brand and Generic settle on under the legal rule $X_{\max }=C_{B}$, and assume that $E^{*}<T$. Efficient bargaining and $E^{*}<T$ imply that $X^{*}=C_{B}$. (Absent the legal constraint on payment size, the Brand would trade a higher payment for an agreement to delay beyond $E^{*}$ that together increased both parties' profits.)

We will compare the settlement $\left[E^{*}, X^{*}\right]$ with the settlement induced by any relaxed legal rule $X_{\max }=X^{* *}>C_{B}$. Let $E^{* *}$ denote the entry date they settle on given this relaxed rule. We now show that $E^{* *}>E^{*}$. If $E^{* *}=T$, then $E^{* *}>E^{*}$, since $E^{*}<T$. Alternatively, if $E^{* *}<T$, then efficient bargaining implies that the reverse payment will equal the maximum $X^{* *}$. Given that $X^{* *}>X^{*}$, the Brand requires some $E^{\prime}>E^{*}$ to achieve the same profit as it achieves under the settlement $\left[E^{*}, X^{*}\right]$. If bargaining is weakly monotonic, then $E^{* *} \geq E^{\prime}>E^{*}$, because the Brand cannot get less profit under the relaxed antitrust rule $X_{\max }=X^{* *}$ than it did under the more stringent rule $X_{\max }=X^{*}$.

Observe that consumer surplus is a decreasing function of $E$, since $S(E)=E M_{S}+H D_{S}+(T-E-H) F_{S}=E\left(M_{S}-F_{S}\right)+H D_{S}+(T-H) F_{S}$ and $M_{S}<F_{S}$. Therefore, the later entry date $E^{* *}$ under the relaxed rule $X_{\max }>C_{B}$ reduces consumer surplus below the level achieved when $X_{\max }=C_{B}$. Later entry also reduces total welfare, since total welfare is lower under monopoly than free entry. Q.E.D.

Proposition \#3 tells us that as $X_{\max }$ increases, the parties move out the Ray of Delay (now possibly a wobbly curve) until $E=T$, at which point they bump into the constraint from patent law that prohibits licensing restrictions that extend beyond the lifetime of the patent. For large enough values of $X_{\max }$, the negotiated settlement involves delay by Generic until $T$ and further increases in $X_{\max }$ will not affect the equilibrium outcome.

Proposition \#3 also tells us that settlements that we would observe with $X>C_{B}$ injure consumers relative to Benchmark \#2, the alternative settlement benchmark. In particular, consider any equilibrium settlement $[X, E]$ with $X>C_{B}$. Such a settlement would only emerge under a relaxed rule, i.e., on the parties' belief that $X_{\max } \geq X>C_{B}$. The settlement that would be chosen instead given the legal rule $X_{\max }=C_{B}$ has higher consumer and total welfare than $[X, E]$ according to Proposition \#3. 


\section{Large Payments Imply Lower Consumer Welfare than Litigation}

Proposition \#2 does not guarantee that a settlement with $X>C_{B}$ has lower consumer welfare compared to litigation. In theory, there exist settlements with $X>C_{B}$ that have higher consumer welfare compared to litigation.

The source of this theoretical possibility is the extra component of Brand's benefit from settlement discussed above, $P H\left(D_{B}-F_{B}\right)$. As a consequence, if Brand has no bargaining power, it is willing to accept a settlement date $E<P T$ to capture that benefit. In particular, if $X=C_{B}$, Brand prefers settlement if and only if $E>P T-P H \frac{D_{B}-F_{B}}{M_{B}-F_{B}}$.

As for consumers, later entry lowers consumer welfare. Consumers require earlier entry, compared to the monopoly-duopoly case, to be indifferent between settlement and litigation. In particular, consumers prefer settlement if and only if $E<P T-P H \frac{F_{S}-D_{S}}{F_{S}-M_{S}}$.

The question thus arises: do there exist settlements with $X=C_{B}$ that are preferred by both Brand and consumers to litigation? Such settlements cannot exist if the earliest entry date that Brand prefer to litigation would make consumers worse off than litigation. Using the two expressions derived just above, we have shown:

Proposition \#4a: Any settlement with $X \geq C_{B}$ that is acceptable to Brand will reduce consumer welfare relative to litigation, provided that

$$
\frac{D_{B}-F_{B}}{M_{B}-F_{B}}<\frac{F_{S}-D_{S}}{F_{S}-M_{S}}
$$

Both of these ratios are less than unity. The left-hand side measures how valuable is duopoly relative to monopoly for Brand, above Brand's free-entry profits. The right-hand side measures how valuable free entry is to consumers compared with duopoly, relative to its value compared to monopoly.

This condition is likely satisfied in practice. A rough estimate can be made using data from a recent FTC study, which evaluated the effect of AGs on drug maker revenues. ${ }^{113}$ The FTC used wholesale expenditures as a proxy for Brand and Generic revenues. ${ }^{114}$ The FTC estimated relative revenue during duopoly and free entry, compared to monopoly, for a large set of drugs experiencing generic entry. On average, Brand retains an

113. See generally FTC, AUTHORIZED GENERIC DRUGS: SHORT-TERM EFFECTS AND LONG-TERM IMPAC'T (2011).

114. Id. at 5. The proxy is imperfect because all figures include a wholesaler margin. 
estimated $52 \%$ of pre-entry revenue during duopoly. ${ }^{115}$ This means that the left-hand side must be less than 0.52.116

Wholesale expenditures can also be used to construct an estimate of the welfare increase in duopoly and free entry compared to monopoly. The main source of increased welfare is reduced outlay for drugs. Based on FTC figures, during duopoly, purchasers save $14 \%$ of the pre-entry price. ${ }^{117}$ In free entry, purchasers save at least $53 \% .{ }^{118}$ Under the assumption that quantities are unchanged, and hence the reduced outlay exactly captures the welfare increase, ${ }^{119}$ the right-hand side is at least $(53 \%-14 \%) / 53 \%=0.74$, and the inequality is satisfied.

These calculations are conservative in two further respects. First, they assume that Brand launches an AG during Generic's exclusivityi.e., that the "duopoly" period includes an AG, in addition to the branded product and independent generic. If Brand agrees to a settlement with a no-AG provision during the 180 days, the inequality widens because $D_{B}$ and $D_{S}$ both fall. Second, the FTC figures assume that Brand receives all of the revenue and profit from the AG. ${ }^{120}$ If Brand receives only part, then $D_{B}$ falls, again widening the inequality. ${ }^{121}$ Finally, we note that if Brand has significant bargaining power then it will be able to bargain for later entry that hurts consumers more.

115. Id. at 108 (reporting Brand relative wholesale expenditure of 0.52 during exclusivity). All estimates are with an AG, unweighted and (where relevant) with full controls.

116. The bound of 0.52 would be achieved if Brands profits under free entry were zero and if Brand profit margin under monopoly and duopoly were equivalent.

117. As noted above, Brand's relative wholesale expenditure during duopoly is 0.52 . The corresponding Generic figure is 0.34 . See id. at 59 tbl.3-7 (reporting 0.70 without AG, and a $52.0 \%$ reduction with an $\mathrm{AG} ; 0.70 *(1-0.520)=0.34)$. The resulting savings is $1.00-$ $0.52-0.34=0.14$.

118. Brand's relative wholesale expenditure during free entry is 0.17 . Id. at 108. The corresponding Generic figure is 0.15 . See id. at 106 tbl.6-4 (reporting 0.31 without AG, and a $52.5 \%$ reduction with an $A G ; 0.31 *(1-0.525)=0.15)$. The share of later entrants is not separately reported by the FTC, but inspection of an accompanying graph reporting contemporaneous shares demonstrates that their combined share is smaller than Generic's share. See id. 104 fig.6-3 (reporting later entrants' combined share to be smaller than Generic in every period). The resulting savings is at least $1.00-0.17-0.15-0.15=0.53$.

119. This assumption is conservative, to the extent that quantities would be expected to increase as prices fall. This assumption overstates the right-hand side to the extent that a post-entry cessation of Brand marketing puts downward pressure on quantity.

120. Id. at 61 n.52 ("Here, all AGs are treated as if they are marketed by a subsidiary of the brand-name company.").

121. To be more precise, a decrease in DB lowers our upper bound on the left hand side of the inequality. 


\section{SETTLEMENT $[E, X]$ WITH MULTIPLE GENERIC ENTRANTS: DURABLE DUOPOLY}

In this section we present and analyze our durable duopoly model of multiple generic entry, in which we assume that no additional generic entry occurs following a settlement, even after the first generic entrant's 180-day exclusivity period ends. Duopoly is therefore significantly more durable in the case of settlement than in the 180-day duopoly model above. This is the assumption made by KWGT. None of the drugs discussed in Part IV fit this pattern. Nevertheless, this pattern is plausible under the right conditions, and could occur if subsequent generics do not find it profitable to enter given that they can be sued for patent infringement and will never enjoy any period of exclusivity. However, as noted above, in practice in most cases multiple generic entry does occur after the 180-day exclusivity period granted to the settling generic ends.

Table 2 gives the expected time spent in monopoly, duopoly, and free entry during the patent period under litigation and under the settlement $[E, X]$ in the durable duopoly model.

\begin{tabular}{|c|c|c|}
\hline $\begin{array}{c}\text { Table 2:Durable } \\
\text { Duopoly Model }\end{array}$ & \multicolumn{2}{|c|}{ Expected Period of Time } \\
\hline & Litigation & Settlement \\
\hline Monopoly & $P T$ & $E$ \\
\hline Duopoly & $(1-P) H$ & $T-E$ \\
\hline Free entry & $\begin{array}{c}T-P T-(1-P) H= \\
(1-P)(T-H)\end{array}$ & 0 \\
\hline
\end{tabular}

\section{Joint Profits from Eliminating Competition}

Now there is an additional benefit to Brand and Generic associated with settlement, since settling prevents free entry from occurring prior to the expiration of the patent. This implies that Proposition \#1 also holds in the model with durable duopoly following settlement.

\section{Brand Payoff from Settlement vs. Litigation}

Brand's payoff from settling on terms $[E, X]$ is now $E M_{B}+(T-E) D_{B}-X$. This is the payoff in the previous model plus the amount $(T-E-H)\left(D_{B}-F_{B}\right)$. This extra amount represents the difference between duopoly and free entry following generic entry at $E$ and the exclusivity period of length $H$. Brand's expected payoff from litigating is $P T M_{B}+(1-P)\left[H D_{B}+(T-H) F_{B}\right]-C_{B}$, just as in the 
previous model. Therefore, there is an additional value of settling in this model equal to $(T-E-H)\left(D_{B}-F_{B}\right)$. Adding this term to the value of settling, settlement on terms $[E, X]$ implies that

$$
(E-P T)\left(M_{B}-F_{B}\right)+P H\left(D_{B}-F_{B}\right)+(T-E-H)\left(D_{B}-F_{B}\right)>X-C_{B} .
$$

The three terms of the left-hand side reflect the benefits to Brand from the settlement. The first two terms are the same as above. The third term is an additional anticompetitive effect of the settlement that accrues to Brand.

\section{Comparison with Monopoly to Duopoly Model}

Now the prospect of multiple generic entry increases the benefits of a settlement that delays entry, for the two reasons described above plus a new reason. The new reason is represented by the final term of the righthand side of the inequality above. As just noted, this term represents the difference between duopoly and free entry following generic entry at $E$ and the exclusivity period of length $H$.

\section{Actavis Inference with Multiple Generic Entrants}

If settlement precludes entry by additional generics until the patent expires, it follows immediately that settlement reduces the expected period of time when consumers benefit from multiple generic competitors. Therefore, the analog to Proposition \#2 is immediate.

\section{Allowing Larger Reverse Payments Harms Consumers and Total Welfare}

The proof of Proposition \#3 applies equally in the model where duopoly is durable following settlement but not following litigation. All that we needed was that consumer surplus and total welfare decline with $E$.

\section{Large Payments Imply Lower Consumer Welfare than Litigation}

The analogue to Proposition \#4a in the durable duopoly model follows:

Proposition \#4b: In the durable duopoly model, any settlement with $X \geq C_{B}$ that is acceptable to Brand will reduce consumer welfare relative to litigation, provided that

$$
\frac{D_{B}-F_{B}}{M_{B}-D_{B}}<\frac{F_{S}-D_{S}}{D_{S}-M_{S}}
$$


In contrast to Proposition \#4a, either of these ratios may exceed unity. As before, the condition is likely satisfied in practice. A rough estimate can be made using the same method, assumptions, and FTC data discussed above. The right-hand side is at least $(53 \%-14 \%) / 14 \%=$ 2.79. ${ }^{122}$ The left-hand side is less than $52 \% /(100 \%-52 \%)=1.08,{ }^{123}$ and thus the inequality is satisfied by a comfortable margin. Once again, these calculations are conservative in the respects discussed above.

BARGaINING Power, BARgaining RANGE AND THE ACTAVIS INFERENCE

Antitrust defendants would prefer a world in which antitrust violations from reverse payment settlements are per se legal so long as the settlements permit entry after $T$. Actavis made clear, however, that pay for delay is illegal and so the question becomes when it is reasonable to infer that a reverse payment settlement involves pay to avoid or delay competition not just payment to avoid litigation cost.

Here, we explore the relationship between the bargaining range, bargaining strength and reductions in competition.

We begin with the simple Monopoly-Duopoly framework of our Activating Actavis paper and move on to consider the multiple entrant models introduced above.

\section{Monopoly-Duopoly Model}

Consider the monopoly-duopoly model of Activating Actavis. Let $E_{B}(X)$ be the entry date that makes Brand indifferent between litigation and settlement with payment $X$. For simplicity, we will usually suppress the argument $\mathrm{X}$ and just write $E_{B}$.

The expected length of monopoly and duopoly periods for settlement $E$ and for litigation in the monopoly-duopoly model are given in Table 3 below.

\begin{tabular}{|c|c|c|}
\hline $\begin{array}{l}\text { Table 3: Monopoly- } \\
\text { Duopoly Model }\end{array}$ & \multicolumn{2}{|c|}{ Expected Period of Time } \\
\hline & Litigation & Settlement \\
\hline Monopoly & $P T$ & $E$ \\
\hline Duopoly & $(1-P) T$ & $T-E$ \\
\hline
\end{tabular}

122. As before, this lower bound assumes constant quantities across the three states. Accounting for quantity changes could make the right hand side significantly larger because the quantity effect could be much larger for the steep price decline from duopoly to free entry than the more modest one from monopoly to duopoly.

123. Much as before, this calculation assumes simply that the profit margin is lower for duopoly than for monopoly. 
A settlement shifts time period $E-P T$ from duopoly to monopoly. Brand pays $X$ and saves $C_{B}$ in litigation cost. Thus, Brand is indifferent between settlement and litigation if

$$
X-C_{B}=\left(E_{B}-P T\right)\left(M_{B}-D_{B}\right) .
$$

If $X=C_{B}$, we see that $E_{B}=P T$. Brand is (just) willing to pay $C_{B}$ to settle with a duopoly period equal in length to the expected duopoly period under litigation.

Next consider Generic. Let $E_{G}(X)$ be the entry date that makes Generic indifferent between litigation and settlement with payment $X$. In the settlement, Generic receives $X$ and saves $C_{G}$ in litigation cost. Generic is willing to accept later entry to receive the payment and save litigation cost. Generic is indifferent between litigation and settlement if

$$
D_{G}\left(E_{G}-P T\right)=X+C_{G} \text {, or } E_{G}=P T+\frac{X+C_{G}}{D_{G}} .
$$

Therefore, in exchange for a payment of $X=C_{B}$, Generic would be willing to delay entry by an (expected) length of time equal to $\frac{C_{B}+C_{G}}{D_{G}}$. This is the (expected) period of time over which duopoly is replaced by monopoly under a settlement that Generic found indifferent to litigation.

Summarizing, if the reverse payment equals Brand's litigation cost, Brand prefers settlement to litigation so long as $E \geq P T$, and Generic prefers settlement to litigation so long as $E \leq P T+\frac{C_{B}+C_{G}}{D_{G}}$. So Generic and Brand bargain over entry dates in the "bargaining range" given by:

$$
P T \leq E \leq P T+\frac{C_{B}+C_{G}}{D_{G}} .
$$

The greater is Brand's bargaining power, the later will be the negotiated entry date, within this range. If Brand has all of the bargaining power, the negotiated entry date will be $P T+\frac{C_{B}+C_{G}}{D_{G}}$. If Generic has all of the bargaining power, the negotiated entry date will be $P T$.

This analysis shows that the Actavis Inference is highly favorable to defendants, in the following specific sense. If Brand has no bargaining power, the Actavis Inference is perfectly accurate in this model. However, if Brand has any bargaining power at all, the Actavis Inference will generate no false antitrust condemnations but will generate some false antitrust acquittals. 
We can make this statement more precise. Brand's bargaining power is defined by $k$, where the negotiated entry date is given by $E=$ $(1-k) E_{B}+k E_{G}$. A value of $k=0$ means that Brand has no bargaining power and the negotiated entry date is the earliest one that is acceptable to Brand, namely $E_{B}$ which equals $P T$. Likewise, a value of $k=1$ means that Brand has all of the bargaining power and the negotiated entry date is the latest one that is acceptable to Generic, namely $E_{G}$ which equals $P T+\frac{X+C_{G}}{D_{G}}$. If Brand's bargaining power is $k$, and if Brand makes a payment to Generic equal to $C_{B}$, then the negotiated entry date is given by $P T+k \frac{C_{B}+C_{G}}{D_{G}}$.

Proposition \#5: If Brand has no bargaining power at all, then the Actavis Inference is perfectly accurate in identifying anticompetitive settlements. If Brand has some bargaining power, the Actavis Inference generates no false condemnations but some false acquittals.

We have not previously emphasized this point in our joint writings, but the Actavis Inference with a litigation cost benchmark is favorable to defendants because by design it minimizes false condemnations without concern for false acquittals. The Actavis Inference is not designed to catch all payments for delay, only the ones where we are sure that there is no false condemnation, regardless of Brand's bargaining power, and we are sure when $X>C_{B}$.

This fact should give the courts significant comfort in applying the Actavis Inference even in cases where defendants try to prove some possible complication that might (if true) make the Inference inapplicable. The false acquittals under the Actavis Inference are not a reason to abandon the Actavis Inference, because doing that would only lead to settlements that are more anticompetitive, as shown in our Proposition \#3. Instead, the false acquittals might provide a reason to strengthen the Actavis Inference or to allow proof of delay from other evidence in cases where the reverse payment is less than litigation costs.

\section{Multiple Generic Entry Models}

An analysis parallel to the preceding analysis can be done for the two multiple generic entry models discussed above. The possibility of multiple generic entry after litigation (or settlement) moves Brand's earliest acceptable entry date $E_{B}$ earlier and Generic's latest acceptable entry date $E_{G}$ later than in the monopoly-duopoly model. Thus, the bargaining range is larger. 
It continues to be the case, regardless of Brand's bargaining power, that settlements with payments in excess of $C_{B}$ involve a reduction in competition from multiple entrants as compared with litigation, as shown in our Proposition \#2, and reduce consumer welfare as shown in Proposition \#3. Hence, the Actavis Inference has no false positives, just as in the monopoly-duopoly model. Furthermore, it continues to be the case that when Brand has some bargaining power, settlements, even ones with payments no larger than $C_{B}$, may involve reductions in competition and consumer welfare. Unlike the monopoly-duopoly model, even when Brand has no bargaining power, settlements with payments less than $C_{B}$ may involve reductions in competition and consumer welfare.

In equilibrium in the model, false acquittals easily arise, especially if Brand has significant bargaining power but even if Brand has no bargaining power. As noted above, this is not a reason to weaken or abandon the Actavis Inference. If anything, it is a reason to provide plaintiffs an opportunity to establish that a reverse-payment settlement is anticompetitive without invoking the Actavis Inference.

\section{APPENDIX B: ERROR-COST ANALYSIS OF ACTAVIS INFERENCE}

The court is attempting to determine whether a challenged reversepayment settlement is or is not anticompetitive. Under the Actavis Inference, a "large and unexplained" reverse payment serves as a "test statistic" indicating that the settlement is anticompetitive. As we explained in Part V, the determination of anticompetitiveness should be made based on the ex ante information the parties had when they entered into their agreement, not based on an ex post determination of patent validity or infringement.

Two types of errors could in principle arise using the Actavis Inference. A false condemnation (Type I Error) arises if the Actavis Inference signals that the settlement is anticompetitive when in fact it is not. A false acquittal (Type II Error) arises if the Actavis Inference does not signal that the settlement is anticompetitive when in fact it is. 
Error Cost Matrix: Applying the Actavis Inference to Settlements Involving Reverse Payments

\begin{tabular}{|c|c|c|}
\hline & $\begin{array}{l}\text { Actavis Inference Applies: } \\
\text { Reverse Payment Exceeds } \\
\text { Litigation Costs }\end{array}$ & $\begin{array}{c}\text { Actavis Inference } \\
\text { Does Not Apply: No } \\
\text { Reverse Payment } \\
\text { Exceeding } \\
\text { Litigation Costs }\end{array}$ \\
\hline $\begin{array}{c}\text { Settlement } \\
\text { Anticompetitive }\end{array}$ & $\begin{array}{l}\text { Accurate Finding of } \\
\text { Antitrust Liability }\end{array}$ & $\begin{array}{l}\text { Type II Error: } \\
\text { False Acquittal }\end{array}$ \\
\hline $\begin{array}{l}\text { Settlement Not } \\
\text { Anticompetitive }\end{array}$ & $\begin{array}{c}\text { Type I Error: } \\
\text { False Condemnation }\end{array}$ & $\begin{array}{l}\text { Accurate Finding of } \\
\text { No Antitrust } \\
\text { Liability }\end{array}$ \\
\hline
\end{tabular}

Propositions \#2 and \#3 establish that there are no false condemnations (Type I errors) in our models. Furthermore, as discussed in the text, the Actavis Inference does generate false acquittals (Type II errors), especially if Brand has significant bargaining power or if there are multiple generic entrants. Weakening the Actavis Inference would generate more false acquittals.

KWGT employ a conception of error costs that conflates patent adjudication with antitrust adjudication. Their mistake is best illustrated by the two-by-two "Error Cost Matrix" in the KWGT Working Paper. ${ }^{124}$ The KWGT rows in that matrix are "Patent Valid" and "Patent Invalid." Their columns are "No Antitrust Violation (Scope of the patent test)" and "Antitrust Violation (Per se illegal)." Their "true" states of the world (the rows) refer to valid and invalid patents, not procompetitive versus anticompetitive settlements. Thus, they are not testing the accuracy of the Actavis Inference in identifying anticompetitive settlements. This fundamental error is fatal to KWGT's entire analysis and discussion of Type I and Type II errors. In particular, KWGT's mistaken claim that the Actavis Inference will "increase the costs of Type I errors" is based on their erroneous conception of what the term "Type I error" means in this context.

124. KWGT Working Paper, supra note 10, at 14. 
*** 